
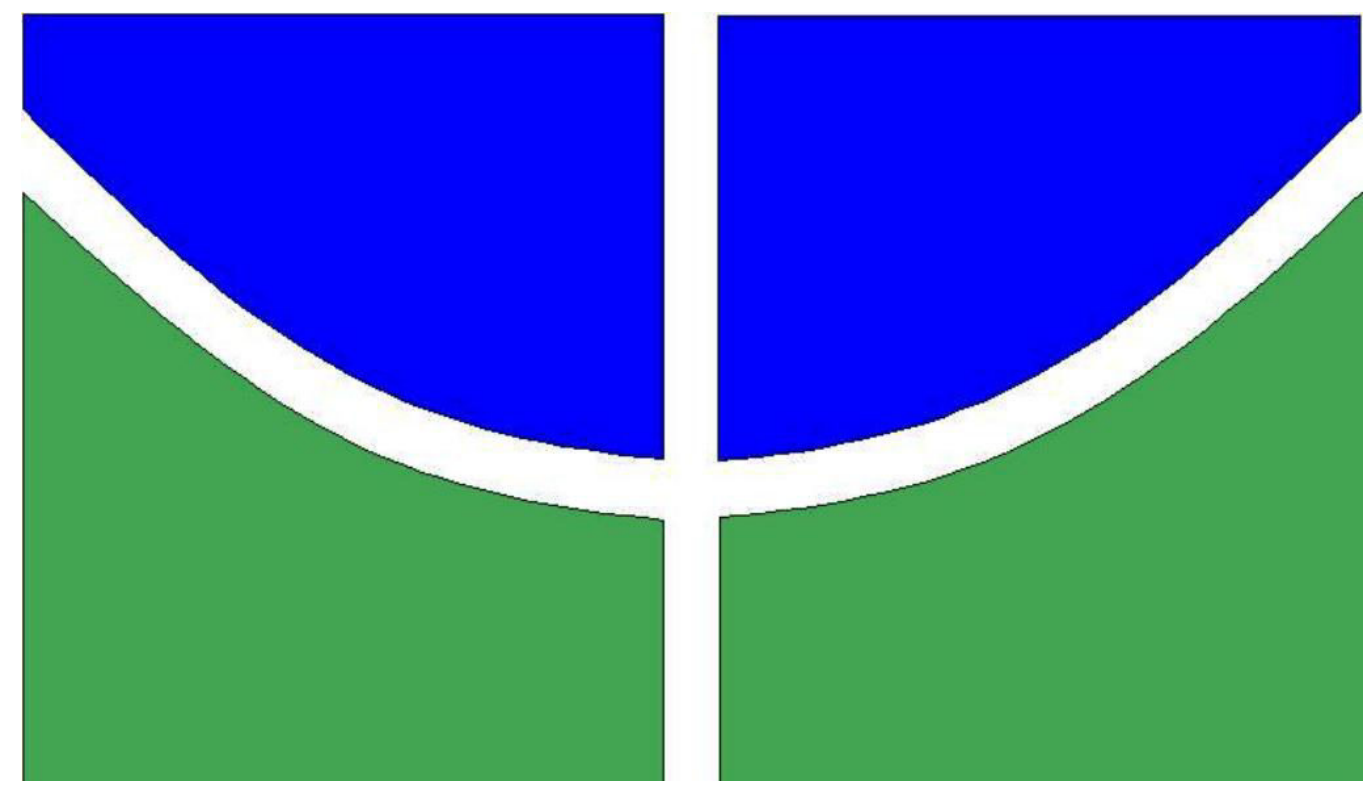

ESTIMATIVA DA PEGADA HÍDRICA CINZA RELATIVA AO FÓSFORO NA BACIA HIDROGRÁFICA DO RIBEIRÃO PIPIRIPAU (DF/GO).

SARAH CAETANO DE FREITAS

DISSERTAÇÃO DE MESTRADO EM CIÊNCIAS FLORESTAIS DEPARTAMENTO DE ENGENHARIA FLORESTAL

FACULDADE DE TECNOLOGIA

UNIVERSIDADE DE BRASÍLIA 
UNIVERSIDADE DE BRASÍLIA

FACULDADE DE TECNOLOGIA

DEPARTAMENTO DE ENGENHARIA FLORESTAL

\section{ESTIMATIVA DA PEGADA HÍDRICA CINZA RELATIVA AO FÓSFORO NA BACIA HIDROGRÁFICA DO RIBEIRÃO PIPIRIPAU (DF/GO).}

SARAH CAETANO DE FREITAS

ORIENTADOR: PROF. DR. HENRIQUE MARINHO LEITE CHAVES

DISSERTAÇÃO DE MESTRADO EM CIÊNCIAS FLORESTAIS

BRASÍLIA/DF, MARÇO - 2013. 
UNIVERSIDADE DE BRASÍLIA

FACULDADE DE TECNOLOGIA

DEPARTAMENTO DE ENGENHARIA FLORESTAL

PROGRAMA DE PÓS-GRADUAÇÃO EM CIÊNCIAS FLORESTAIS

ESTIMATIVA DA PEGADA HÍDRICA CINZA RELATIVA AO FÓSFORO NA

BACIA HIDROGRÁFICA DO RIBEIRÃO PIPIRIPAU

SARAH CAETANO DE FREITAS

DisSERTAÇ̃̃o DE MESTRAdO SUBMETIDA AO PROGRAMA DE PÓSGRADUAÇÃ̃O EM CIÊNCIAS FLORESTAIS, DO DEPARTAMENTO DE ENGENHARIA FLORESTAL, DA FACULDADE DE TECNOLOGIA DA UNIVERSIDADE DE BRASÍLIA, COMO PARTE DOS REQUISITOS NECESSÁRIOS PARA A OBTENÇÃO DO GRAU DE MESTRE.

APROVADA POR:

Prof. Dr. Henrique Marinho Leite Chaves (Departamento de Engenharia Florestal, UnB);

(Orientador)

Prof. Dr. Reuber Albuquerque Brandão (Departamento de Engenharia Florestal, UnB);

(Examinador interno)

Prof. Dr. Mauricio Augusto Leite (Universidade Estadual Paulista - UNESP);

(Examinador externo)

Prof. Dr. Mauro Eloi Nappo (Departamento de Engenharia Florestal, UnB);

(Examinador suplente) 


\section{FICHA CATALOGRÁFICA}

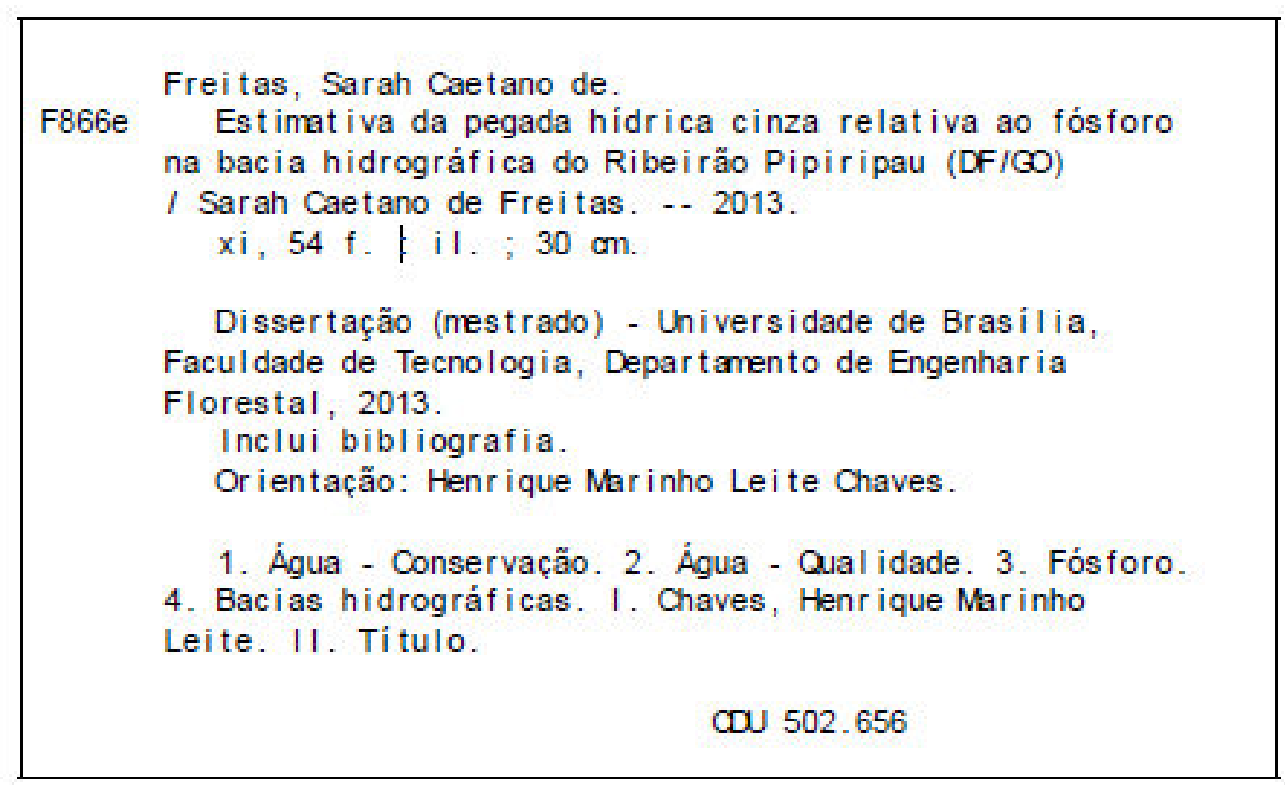

\section{REFERÊNCIA BIBLIOGRÁFICA}

Freitas, S.C. (2013). Estimativa da pegada hídrica cinza relativa ao fósforo na bacia hidrográfica do ribeirão Pipiripau. Dissertação de mestrado, Publicação PPG EFL. DM 208/2013, Departamento de Engenharia Florestal, Universidade de Brasília, DF, 54p.

\section{CESSÃO DE DIREITOS}

AUTOR: Sarah Caetano de Freitas

TÍTULO: Estimativa da pegada hídrica cinza relativa ao fósforo na bacia hidrográfica do ribeirão Pipiripau.

GRAU: Mestre $\quad$ ANO: 2012

É concedida à Universidade de Brasília permissão para reproduzir cópias desta dissertação de mestrado e para emprestar ou vender tais cópias somente para propósitos acadêmicos e científicos. O autor reserva outros direitos de publicação e nenhuma parte dessa dissertação de mestrado pode ser reproduzida sem autorização por escrito do autor. 


\section{DEDICATÓRIA}

A Deus, autor da minha fé.

Ao meu amado esposo e nosso tão esperado filho (Igor).

A todas as pessoas que de alguma forma me ajudaram. 


\section{AGRADECIMENTOS}

De gratos louvores transborda o meu coração a Ti, meu Deus. Tú és o motivo maior da minha gratidão! Em minhas limitações me deste auxílio e em meu desânimo, me levantaste. A Ti toda honra!

Agradeço ao meu precioso esposo por sua paciência, dedicação e amor. Essa vitória é sua também!

Aos meus pais, Carlos e Cirlei e irmãos, Thiago e Rebeca, que mesmo distante, torceram e oraram por mim.

Aos meus sogros Nelson e Fátima, por todo apoio e incentivo.

Ao meu orientador, Henrique Chaves, pelas horas dedicadas, pelas dúvidas respondidas e pelo conhecimento ministrado.

Ao Dr. Reginaldo, ao Pedro e ao Chiquinho pela pronta ajuda nas questões administrativas ligadas à pós - graduação.

Ao Prof. Dr. Maurício e ao Prof. Dr. Reuber, por aceitarem participar da banca examinadora.

Às amigas de universidade, Alessandra e Silvania, pelos desabafos e auxílio nesses dois anos. Foi muito bom contar com vocês!

Ao Marcos, pelos dados experimentais e pelas conversas descontraídas.

Aos amigos mais chegados que irmãos, de Brasília e Ilha - Solteira. O apoio de vocês me fez mais forte. 


\title{
RESUMO
}

\section{ESTIMATIVA DA PEGADA HÍDRICA CINZA RELATIVA AO FÓSFORO NA BACIA HIDROGRÁFICA DO RIBEIRÃO PIPIRIPAU (DF/GO)}

\author{
Autor: Sarah Caetano de Freitas \\ Orientador: Henrique Marinho Leite Chaves \\ Programa de pós - graduação em Ciências Florestais \\ Brasília, Março de 2013.
}

Devido à intensa ocupação por lavouras e outras atividades agropecuárias e urbanas, a bacia hidrográfica do ribeirão Pipiripau tem sofrido grandes pressões ambientais nos últimos 50 anos. Essas alterações ameaçam a qualidade da água do ribeirão pelo aumento do consumo e pela quantidade de sedimentos e nutrientes que são carreados ao corpo d'água. O fósforo é um dos nutrientes levados com o sedimento erodido, contribuindo para a eutrofização dos ecossistemas aquáticos. Nesse contexto, a avaliação da pegada hídrica cinza do fósforo é uma interessante ferramenta de gestão ambiental, contribuindo para o planejamento e adoção de medidas de controle da poluição das águas. $\mathrm{O}$ valor da pegada hídrica cinza para as condições atuais de uso e ocupação do solo da bacia, calculada pelos coeficientes de exportação de fósforo total, foi de $0,04 \mathrm{~m}^{3} / \mathrm{s}$, sendo menor do que o valor da pegada hídrica cinza calculada pela concentração de fósforo total na água do ribeirão Pipiripau, de $0,07 \mathrm{~m}^{3} / \mathrm{s}$. Os diferentes cenários de uso e ocupação do solo apresentaram valor de pegada hídrica de $0,05 \mathrm{~m}^{3} / \mathrm{s}$ (cenário $100 \%$ agrícola), de $0,12 \mathrm{~m}^{3} / \mathrm{s}$ (cenário $100 \%$ urbano), de $0,006 \mathrm{~m}^{3} / \mathrm{s}$ (cenário $100 \%$ cerrado), e de $0,09 \mathrm{~m}^{3} / \mathrm{s}$ (cenário $50 \%$ agrícola e $50 \%$ urbano). As pegadas hídricas cinza para a condição atual e para os diferentes cenários de uso e ocupação do solo se mostraram ambientalmente sustentáveis, estando dentro dos limites dos padrões de qualidade da água em seu estado natural.

Palavras - chaves: Qualidade da água, coeficiente de exportação, uso e ocupação do solo, capacidade de assimilação de fósforo. 


\section{ABSTRACT \\ EVALUATION OF THE GRAY WATER FOOTPRINT (PHOSPHORUS) IN THE PIPIRIPAU RIVER BASIN (DF/GO)}

Author: Sarah Caetano de Freitas

Supervisor: Henrique Marinho Leite Chaves

Programa de pós - graduação em Ciências Florestais

Brasília, March 2013

Due to increasing urbanization and land use changes, the Pipiripau river basin has experienced high environmental pressures in the last 50 years. These changes threaten the water quality of the river not only by increased water abstraction, but also by sediment and nutrients that are carried to the water body. Phosphorus is carried adsorbed in the sediment and may lead to the eutrophication of the aquatic ecosystem. The gray water footprint assessment serves as a tool for environmental management, contributing for the planning and control of water pollution. The gray water footprint $(\mathrm{P})$ for actual land use conditions, calculated with phosphorus export coefficients in the literature was $0,04 \mathrm{~m}^{3} / \mathrm{s}$, as opposed to $0,07 \mathrm{~m}^{3} / \mathrm{s}$, which was the gray water footprint calculated using the phosphorus concentration of river water. The different land use scenarios yielded a gray water footprint of $0,05 \mathrm{~m}^{3} / \mathrm{s}(100 \%$ agrícultural $), 0,12 \mathrm{~m}^{3} / \mathrm{s}$ (100\% urban), $0,006 \mathrm{~m}^{3} / \mathrm{s}(100 \%$ savannah), and $0,09 \mathrm{~m}^{3} / \mathrm{s}(50 \%$ agrícultural $+50 \%$ urban). All gray water footprints for the actual conditions and differents scenarios were environmentally sustainable, being within the limits of water quality standards in its natural state.

Keywords: Water quality, export coefficient, land use and ocupation, assimilative capacity of phosphorus. 


\section{SUMÁRIO}

1 INTRODUÇÃ 0 .................................................................................................................... 1

2 OBJETIVOS .................................................................................................

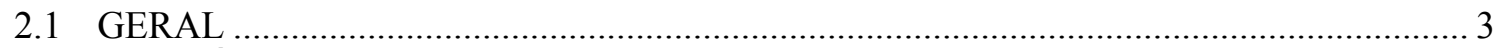

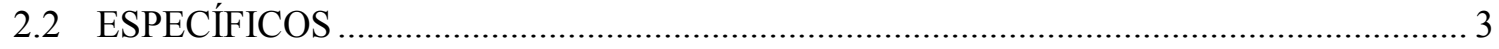

3 REVISÃO BIBLIOGRÁFICA .................................................................................. 3

3.1 A BACIA HIDROGRÁFICA: CONCEITO, PRESSÕES AMBIENTAIS E SUA GESTÃO. 3

3.2 BACIA HIDROGRÁFICA DO RIBEIRÃO PIPIRIPAU: OCUPAÇÃO TERRITORIAL E

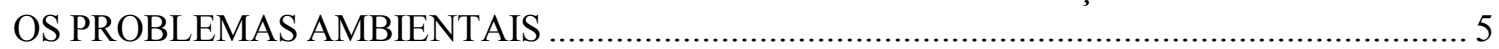

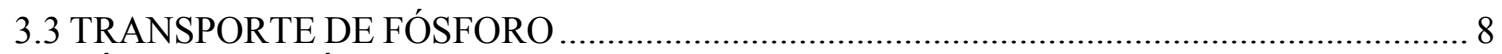

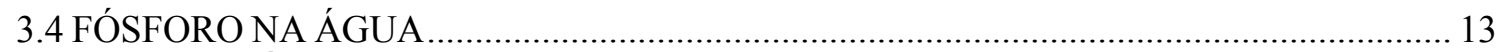

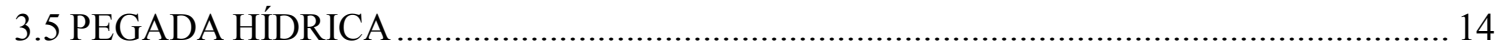

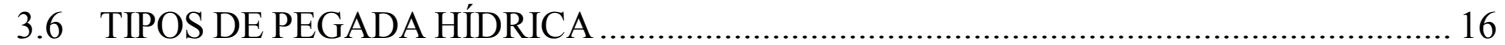

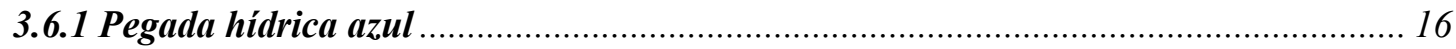

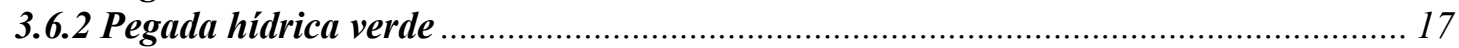

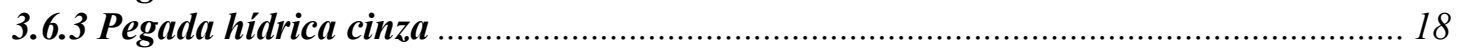

3.7 AVALIAÇÃO DA PEGADA HÍDRICA ..................................................................... 19

3.7.1 Limitaçães da avaliação da pegada hídrica ……………………………………....... 20

4 MATERIAIS E MÉTODOS...............................................................................................21

4.1 LOCALIZAÇÃO E CARACTERIZAÇÃO DA ÁREA DE ESTUDO ……………………......2

4.2 AVALIAÇÃO DA PEGADA HÍDRICA CINZA DA BACIA …………………………......2

4.2.1 Definição de objetivos e escopos ..........................................................................26

4.2.1.1 Definição de objetivos...................................................................................2 26

4.2.1.2 Definição de escopos .......................................................................................2 26

4.2.2 Contabilização da pegada hídrica cinza ………………........................................ 28

4.2.2.1 Agrupamento das classes de uso e ocupação do solo ………………………... 29

4.2.2.2 Cálculo da carga poluente (L) (................................................................... 30

4.2.2.3 Relação de aporte de sedimento (RAS) e fósforo total …………………..... 32

4.2.2.4 Estimativa da concentração máxima de fósforo total no corpo d'água .......34

4.2.2.5 Estimativa da concentração natural de fósforo total no corpo d'água ........34

4.2.3 Cálculo da pegada hídrica usando o valor da concentração de fósforo total medida. 35

4.2.4 Cálculo da pegada hídrica cinza em diferentes condiçães de uso e ocupação do solo 36

4.2.5 Avaliação da sustentabilidade da pegada hídrica cinza ............................................ 36

4.2.6 Formulação da resposta da pegada hídrica.......................................................... 38

5 RESULTADOS E DISCUSSÃO................................................................................... 38

5.1 CARGA DE FÓSFORO TOTAL NA BACIA ………………………………………….... 38

5.2 CÁLCULO DA CARGA DE FÓSFORO TOTAL NO EXUTÓRIO DA BACIA ................... 39

5.3 ESTIMATIVA DA CONCENTRAÇÃO NATURAL DE FÓSFORO TOTAL DO CORPO

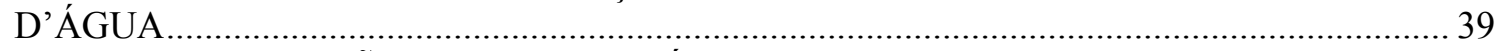

5.4 CONTABILIZAÇ̃̃O DA PEGADA HÍDRICA CINZA (P).................................................. 40

5.5 CÁLCULO DA PEGADA HÍDRICA USANDO O VALOR DA CONCENTRAÇÃ̃ DE

FÓSFORO TOTAL MEDIDO NA ÁGUA ………………………………………………........ 40

5.6 CÁLCULO DA PEGADA HÍDRICA CINZA EM DIFERENTES CONDIÇÕES DE USO E

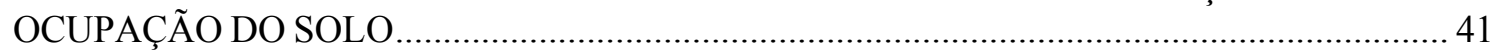

5.6.1 Pegada Hídrica no Cenário 1............................................................................... 41

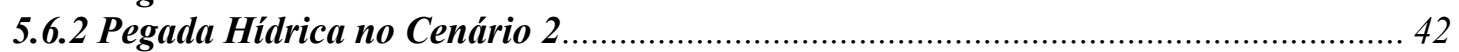

5.6.3 Pegada Hídrica no Cenário 3............................................................................. 42

5.6.4 Pegada Hídrica no Cenário 4........................................................................... 42

5.7 AVALIAÇÃO DA SUSTENTABILIDADE DA PEGADA HÍDRICA CINZA ……………... 44

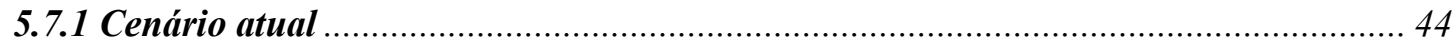


5.7.2 Cenário 1 (100\% de agricultura na bacia)

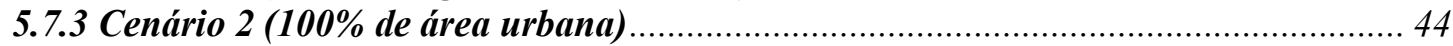

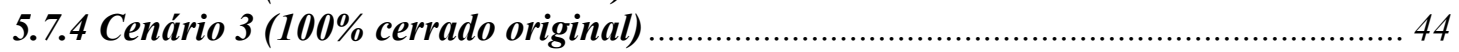

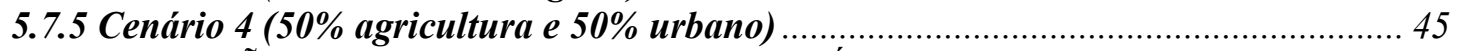

5.8 FORMULAÇÃO DE RESPOSTAS DA PEGADA HÍDRICA CINZA................................... 47

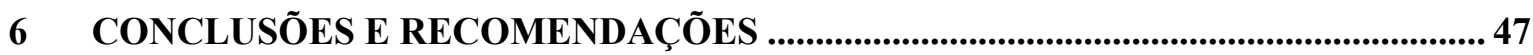

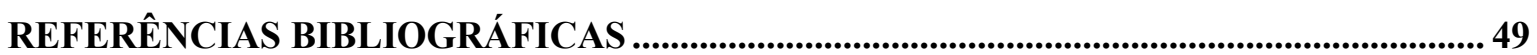




\section{LISTA DE TABELAS}

Tabela 4.1- Uso e ocupação do solo da bacia hidrográfica do ribeirão Pipiripau 23

Tabela 4.2 - Níveis de resolução espaço-temporal das pegadas hídricas.............................27

Tabela 4.3 - Agrupamento das classes de uso do solo.........................................................29

Tabela 4.4 - Valores de coeficientes de exportação de fósforo para as três principais classes de uso e ocupação do solo da bacia do Pipiripau....

Tabela 4.5 - Valores de coeficientes de exportação de fósforo de acordo com o uso e ocupação do solo. 32

Tabela 5.1 - Multiplicação da área da classe de cada uso e cupação do solo pelo coeficiente de exportação de cada classe. 


\section{LISTA DE FIGURAS}

Figura 3.1 - Áreas da bacia do ribeirão Pipiripau que apresentam erosão atual acelerada. Fonte: CHAVES (2012, não publicado).

Figura 3.2 - Mapa de erosão da bacia do ribeirão Pipiripau em sua condição de vegetação original (1953). Fonte: CHAVES (2012, não publicado).................................................. 8 Figura 3.3 - Perda de solo atual na bacia do ribeirão Pipiripau. Fonte: CHAVES (2012, não publicado)

Figura 4.1 - Perda de solo atual na bacia do ribeirão Pipiripau. Fonte: Chaves (2012, não publicado)

Figura 4.2 - Setorização da bacia e localização dos núcleos urbanos. Fonte: BRASIL (2010).

Figura 4.3 - Mapa de uso e ocupação do solo da bacia hidrográfica do ribeirão Pipiripau. Fonte: TNC (2009).

Figura 4.4 - Mapa da declividade (\%) da bacia hidrográfica do ribeirão Pipiripau. Fonte: Chaves (2012, não publicado)

Figura 4.5 - Pedologia da bacia do ribeirão Pipiripau. Fonte: Chaves (2012, não publicado)

Figura 5.1 - Comparação da pegada hídrica cinza calculada com o uso de coeficientes de exportação e com o valor da concentração de fósforo na água. Fonte: autoria própria (2013).

Figura 5.2 - Pegada hídrica cinza $\left(\mathrm{m}^{3} / \mathrm{s}\right)$ usando coeficientes de exportação em relação ao uso e ocupação do solo. Fonte: autoria própria (2013). Figura 5.3 - Capacidade de assimilação do fósforo (WPL) em relação a diferentes usos e ocupação do solo. Fonte: autoria própria (2013). .45 


\section{INTRODUÇÃO}

A qualidade da água de uma bacia hidrográfica pode ser influenciada por diversos fatores, tais como a cobertura vegetal, a topografia, a geologia, o uso/ manejo do solo e a área de entorno. Esses fatores são responsáveis pelo aporte de sedimento e de nutrientes que serão carreados aos cursos d'água (BASNYAT et al., 2000) e, consequentemente, modificar suas características físicas, químicas e biológicas.

A Bacia hidrográfica do Ribeirão Pipiripau, localizada na porção nordeste do Distrito Federal, tem sofrido pressões ambientais ao longo dos últimos 50 anos. Isto se deve, principalmente, ao aumento da urbanização e ao crescimento da atividade agropecuária. Esses processos levam, necessariamente, ao aumento do consumo de água e também à produção de resíduos de vários tipos que ameaçam a qualidade da água do ribeirão (COMITÊ DA BACIA HIDROGRÁFICA DO RIO PARANAÍBA - CBH - PARANAÍBA, 2012).

Na bacia há uma significativa produção de grãos e hortifrútis, que abastece o Distrito Federal e as redondezas. Entretanto, para Chaves (2012, não publicado), a conversão das áreas naturais da bacia, originalmente sob Cerrado, para áreas agrícolas, pecuárias e urbanas, leva a um significativo impacto para a quantidade e qualidade de água, impacto esse que vem ameaçando a sustentabilidade hídrica da bacia.

Chaves et al. (2004) relatam que a maior parte dos produtores rurais da bacia não utiliza práticas e manejos conservacionistas em suas propriedades, e como os solos são relativamente erodíveis, os mesmos sofrem um processo de erosão acelerada durante o período chuvoso (outubro a maio). Dessa forma, o sedimento gerado nas glebas e fazendas é levado pelas enxurradas, chegando aos cursos d'água da bacia.

A eutrofização artificial das águas faz parte do processo de degradação dos corpos hídricos e tem estreita relação com o aumento da sedimentação pela ação erosiva da água sobre o solo. De acordo com Leopold (1970), esse processo se refere à excessiva adição de nutrientes, geralmente em referência a atividades antropogênicas e à adição de fósforo e nitrogênio às águas naturais. 
Para Pellegrini (2005), a presença de fósforo na água bruta tem proporcionado preocupações ambientais e sanitárias, especialmente nos países economicamente desenvolvidos. Essas preocupações não se devem apenas ao fato do fósforo ser um contaminante em si, mas por ser considerado o elemento que mais contribui no desencadeamento da eutrofização dos ecossistemas aquáticos.

Como consequências do processo de eutrofização dos corpos hídricos, Paulino, França e Ferreira (2007) destacam o incremento na concentração de matéria orgânica, a anoxia (falta de oxigênio) nas maiores profundidades e eventualmente em toda a coluna d'água, a floração de cianobactérias, a perda de biodiversidade, a possível produção de toxinas por espécies de cianobactérias, a proliferação de macrófitas aquáticas, o incremento nos custos do tratamento da água para consumo humano e a deterioração dos valores recreacionais do corpo hídrico.

Devido às modificações físicas, químicas e biológicas que os corpos d'água podem sofrer pelo aporte de sedimento bem como pela eutrofização, a realização de estudos de qualidade da água em bacias hidrográficas é de extrema importância, pois possibilitam a proposição de medidas mitigadoras para a redução dos impactos ambientais e incentivam a comunidade a utilizar de forma consciente os recursos naturais disponíveis.

Nesse contexto, a pegada hídrica cinza, um indicador de poluição hídrica recentemente desenvolvido, é de grande valia como uma ferramenta de gestão de recursos hídricos, uma vez que, por meio dela é calculado o volume de água necessário para a assimilação de uma carga poluente, baseada nas concentrações naturais e nos lançamentos, contribuindo para o planejamento e adoção de medidas de controle da poluição das águas.

Entretanto, em função de seu recente desenvolvimento, a pegada hídrica cinza apresenta limitações em sua metodologia e, apesar de o número de aplicações do conceito pegada hídrica estar crescendo rapidamente, ainda existem poucos estudos com foco em bacias hidrográficas específicas. Dessa forma, este trabalho aporta mais informações e dados visando à avaliação da pegada hídrica em bacias hidrográficas, no tocante a um poluente específico. 


\section{OBJETIVOS}

\subsection{GERAL}

Avaliar a pegada hídrica cinza, no tocante ao fósforo, na condição de uso e ocupação atual do solo da bacia hidrográfica do ribeirão Pipiripau e em outros cenários hipotéticos.

\subsection{ESPECÍFICOS}

- Estimar a carga difusa de fósforo total que é transportada para o exutório do ribeirão Pipiripau, associada ao uso e ocupação do solo da bacia hidrográfica;

- Calcular a pegada hídrica cinza do fósforo total na bacia do Pipiripau;

- Verificar se a pegada hídrica cinza do fósforo total da bacia é sustentável;

- Comparar a pegada hídrica cinza obtida por meio do uso de coeficientes de exportação de fósforo total das áreas antrópicas com aquela obtida por meio dos valores de concentração de fósforo total medidos no ribeirão;

- Comparar a pegada hídrica cinza na condição atual da bacia com aquelas sob diferentes cenários hipotéticos de uso e manejo do solo;

- $\quad$ Propor medidas mitigadoras para a redução da pegada hídrica cinza do fósforo total da bacia.

\section{REVISÃO BIBLIOGRÁFICA}

\subsection{A BACIA HIDROGRÁFICA: CONCEITO, PRESSÕES AMBIENTAIS E SUA GESTÃO.}

A bacia hidrográfica é uma área de captação natural da água de precipitação que faz convergir o escoamento para um único ponto de saída. A bacia hidrográfica compõe-se de um conjunto de superfícies vertentes e de uma rede de drenagem formada por cursos de água que confluem até resultar em um leito único no seu exutório (PORTO, M.; PORTO, R., 2008).

A bacia hidrográfica pode ser então considerada um sistema. Nela se realizam os balanços de entrada proveniente da chuva e saída de água através do exutório, permitindo que sejam delineadas bacias e sub-bacias, cuja interconexão se dá pelos sistemas hídricos (PORTO, M.; PORTO, R., 2008). 
Para MUSETTI (2000) a bacia hidrográfica deve ser entendida como a unidade ecossistêmica e morfológica que permite a análise e entendimento dos problemas ambientais. Ela também é perfeitamente adequada para um planejamento e manejo, buscando otimizar a utilização dos recursos humano e natural, para estabelecer um ambiente sadio e um desenvolvimento sustentado.

Sobre o território definido como bacia hidrográfica é que se desenvolvem as atividades humanas. Todas as áreas urbanas, industriais, agrícolas ou de preservação fazem parte de alguma bacia hidrográfica. Pode-se dizer que, no seu exutório, estarão representados todos os processos que fazem parte do seu sistema. O que ali ocorre é consequência das formas de ocupação do território e da utilização das águas que para ali convergem (PORTO, M.; PORTO, R., 2008).

Apesar de toda importância ambiental, social e econômica que as bacias hidrográficas oferecem, muitas delas têm sofrido perturbações e poucas medidas de recuperação e gestão ambiental são realizadas. Araújo et al. (2009) relatam que, na América do Sul, as bacias hidrográficas têm sido consideravelmente alteradas nos últimos anos em função do desenvolvimento industrial, do crescimento desordenado das cidades e da superpopulação, além de diversas atividades antrópicas potencialmente impactantes que se instalam de forma não planejada, ao longo das bacias (ARAÚJO et al., 2009).

Dias e Griffith (1998) citam alguns exemplos de alterações nas bacias hidrográficas que podem ocorrer por diversas finalidades. Dentre as alterações estão os desmatamento para fins de agricultura, a urbanização, as obras de engenharia para construção de estradas, ferrovias ou represas, a mineração a céu aberto, a superexploração da vegetação, as atividades com uso excessivo de defensivos agrícolas, a falta de práticas conservacionistas do solo e as atividades industriais/ bioindustriais.

A degradação ambiental nas áreas de recarga, provocada por desmatamentos desordenados, compactação e erosão de solos, não só afeta o potencial de evapotranspiração (e conseqüente produção de água limpa para o ciclo hidrológico), como também provoca escorrimentos superficiais excessivos, que carreiam sedimento e dejetos, os quais irão depositar-se nos grandes reservatórios, tendo como resultado o assoreamento e a poluição ambiental. As conseqüências desses fenômenos, segundo Santana (2003), são o comprometimento da capacidade produtiva nas propriedades rurais, além da redução na 
capacidade de armazenamento dos grandes reservatórios, comprometendo a produção de energia. O efeito conjunto desses vários fatores é a deterioração das bacias hidrográficas.

A degradação ambiental e suas alterações no meio ambiente são as mais graves ameaças que a humanidade enfrentará neste século. Isso porque essas mudanças fazem parte de uma cadeia de processos muito tênues que se rompe muito facilmente. Não raros são os estudiosos que já usam a expressão tipping point (ponto de não retorno), indicando o ponto em que as mudanças ambientais já se tornarão irreversíveis. Calcula-se que no ritmo atual de degradação pelo qual passam os Cerrados no Brasil os mesmos estarão praticamente extintos até 2030 (LIMA, 2009).

Dessa forma, uma gestão ambiental nas bacias hidrográficas é de extrema importância a fim de minimizar e prevenir maiores danos futuros.

Para Porto, M. e Porto, R. (2008), uma gestão sustentável dos recursos hídricos das bacias hidrográficas necessita de um conjunto mínimo de instrumentos principais:

- Uma base de dados e informações socialmente acessível;

- A definição clara dos direitos de uso;

- O controle dos impactos sobre os sistemas hídricos;

- O processo de tomada de decisão.

Com a gestão ambiental por bacia hidrográfica, a atividade econômica deve adequar- se à capacidade de carga natural do ambiente, para regenerar as entradas de recursos no sistema e assimilar os fluxos de resíduos da atividade produtiva, sem ultrapassar o limite da sustentabilidade do ambiente no longo prazo (CAMPOS, 2010).

\subsection{BACIA HIDROGRÁFICA DO RIBEIRÃO PIPIRIPAU: OCUPAÇÃO TERRITORIAL E OS PROBLEMAS AMBIENTAIS}

A colonização da região onde se encontra a bacia do Pipiripau iniciou-se ainda na década de 1960. Antes da construção da capital, o local era constituído por grandes fazendas que, com o passar dos anos, foram desapropriadas e parceladas (BRASIL, 2010).

Tendo por inspiração a política nacional de incentivo à ocupação do Cerrado, iniciou- se a 
criação dos núcleos rurais do DF, transferindo para o Planalto Central produtores das Regiões Sul e Sudeste. A esses produtores eram disponibilizados créditos subsidiados, infraestrutura básica (estradas e eletrificação) e terras arrendadas em Núcleos Rurais (CBH - PARANAÍBA, 2012).

De acordo com Brasil (2010), a criação dos núcleos rurais instalados na bacia ocorreu no período de 1977 a 1983 e são compostos de lotes/chácaras e áreas isoladas que são cedidos aos produtores por meio de contratos de arrendamento e/ou permissão de uso. Além dos arrendamentos, também há terras particulares e lotes ocupados por posseiros, inclusive, um assentamento do Movimento dos Trabalhadores Rurais Sem Terra-MST.

Destaca-se o grande crescimento populacional da bacia do Pipiripau ocorrido no período entre 1991 e 1996. Nesse período, a taxa média de crescimento anual da população residente na bacia foi da ordem de $20 \%$, quatro vezes superior à de Planaltina e aproximadamente oito vezes superior à do Distrito Federal (CBH - PARANAÍBA, 2012).

-Esse indicador revela um alto nível de pressão antrópica na região, especialmente em face da urbanização acelerada. Esse processo leva, necessariamente, ao aumento do consumo de água e também à produção de resíduos de vários tipos que ameaçam a qualidade da água do ribeirão (CBH - PARANAÍBA, 2012).

Diante da ocupação territorial e do grande crescimento populacional, a bacia do ribeirão Pipiripau passou, nos últimos 50 anos, por uma forte conversão da sua vegetação natural (fisionomias típicas de cerrado) para agricultura e pecuária (CHAVES, 2012, não publicado).

São observados na bacia diversos conflitos pelo uso da água. Nos últimos anos, porém, esses conflitos foram agravados devido à entrada em funcionamento do canal de irrigação Santos Dummont e à captação de água da CAESB.

O processo erosivo na bacia do Pipiripau é demonstrado na Figura 3.1, onde $40 \%$ da área total da bacia sofrem perda de solo inferior a 5 t/ha.ano, enquanto $8,5 \%$ da bacia apresentam taxas de erosão superiores a 20 t/ha.ano. Uma vez que a erosão acelerada ocorre a partir de 10 t/ha.ano, 23,8 \% da área total da bacia sofre o processo de erosão acelerada (ou 5.600 ha). 


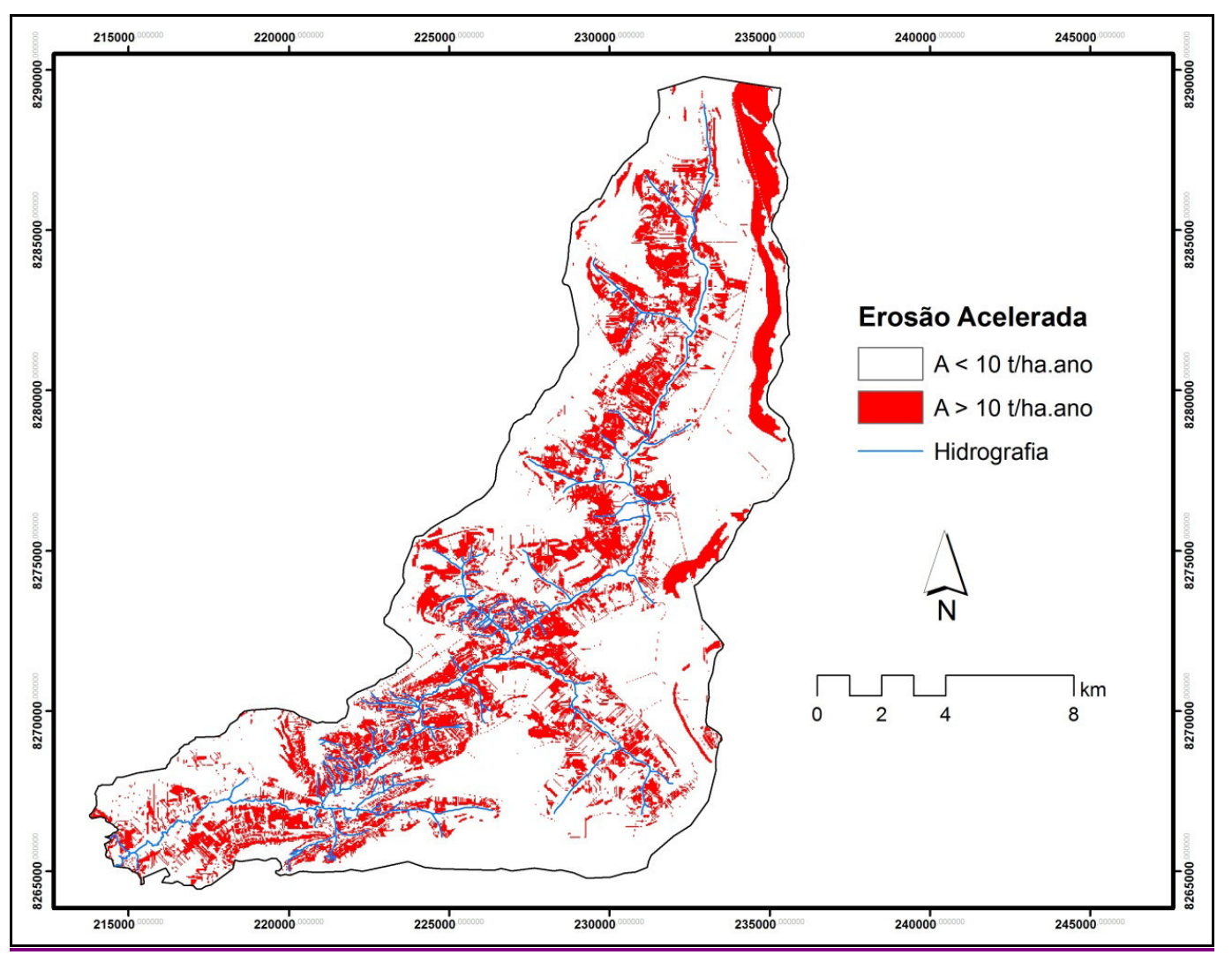

Figura 3. 1 - Áreas da bacia do ribeirão Pipiripau que apresentam erosão atual acelerada. Fonte: CHAVES (2012, não publicado).

De acordo com Chaves (2012, não publicado), a área total da bacia apresentando erosão acelerada (23,8\%, ou 5.600 ha), a qual é fonte potencial de sedimentação (A > 10 t/ha.ano), é um número bastante significativo para uma bacia de abastecimento de água.

Comparando a erosão na condição natural (original, em 1953) da bacia e a erosão natural demonstrada nas figuras 3.2 e 3.3, podemos observar que as maiores taxas erosivas ocorrem nas áreas de maior declividade e de maior comprimento de rampa, situadas próximas à rede de drenagem da bacia, sobre solos erodíveis. Chaves (2012, não publicado) relata que essas áreas representam um grande risco à sedimentação dos cursos d'água, sendo fontes preferenciais de geração de sedimento, devendo merecer especial atenção em programas conservacionistas.

A maior parte da bacia apresentava, em 1953, perdas de solo inferiores a 2,5 t/ha.ano. A perda de solo média, naquela ocasião, era de apenas 0,7 t/ha.ano, ou seja, 12 vezes inferior à perda de solo média atual na bacia (que é de aproximadamente $8,2 \mathrm{t} / \mathrm{ha}$.ano). Isso demonstra a importância do tipo de uso do solo na proteção contra a erosão (CHAVES, 2012, não publicado). 


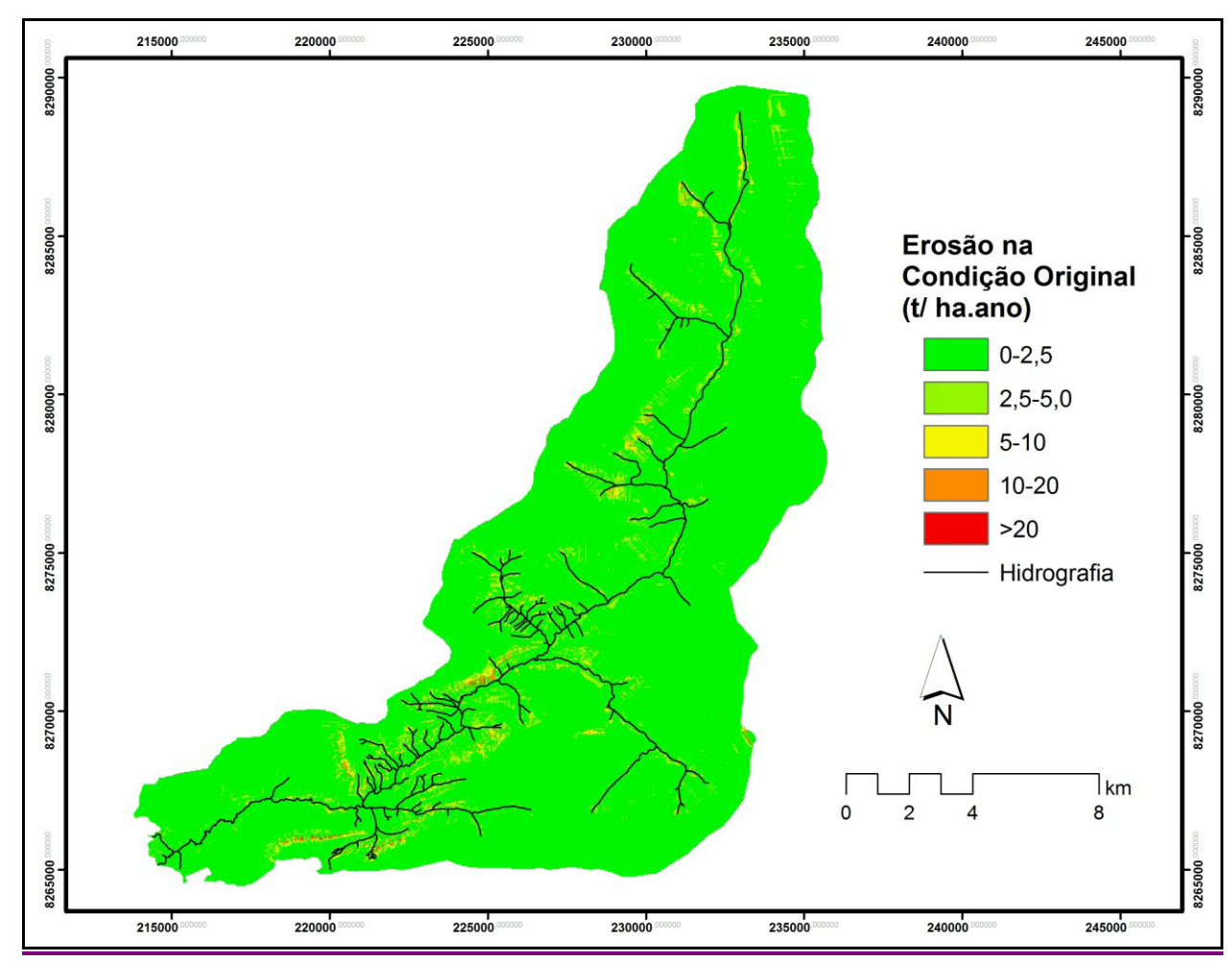

Figura 3. 2 - Mapa de erosão da bacia do ribeirão Pipiripau em sua condição de vegetação original (1953). Fonte: CHAVES (2012, não publicado).

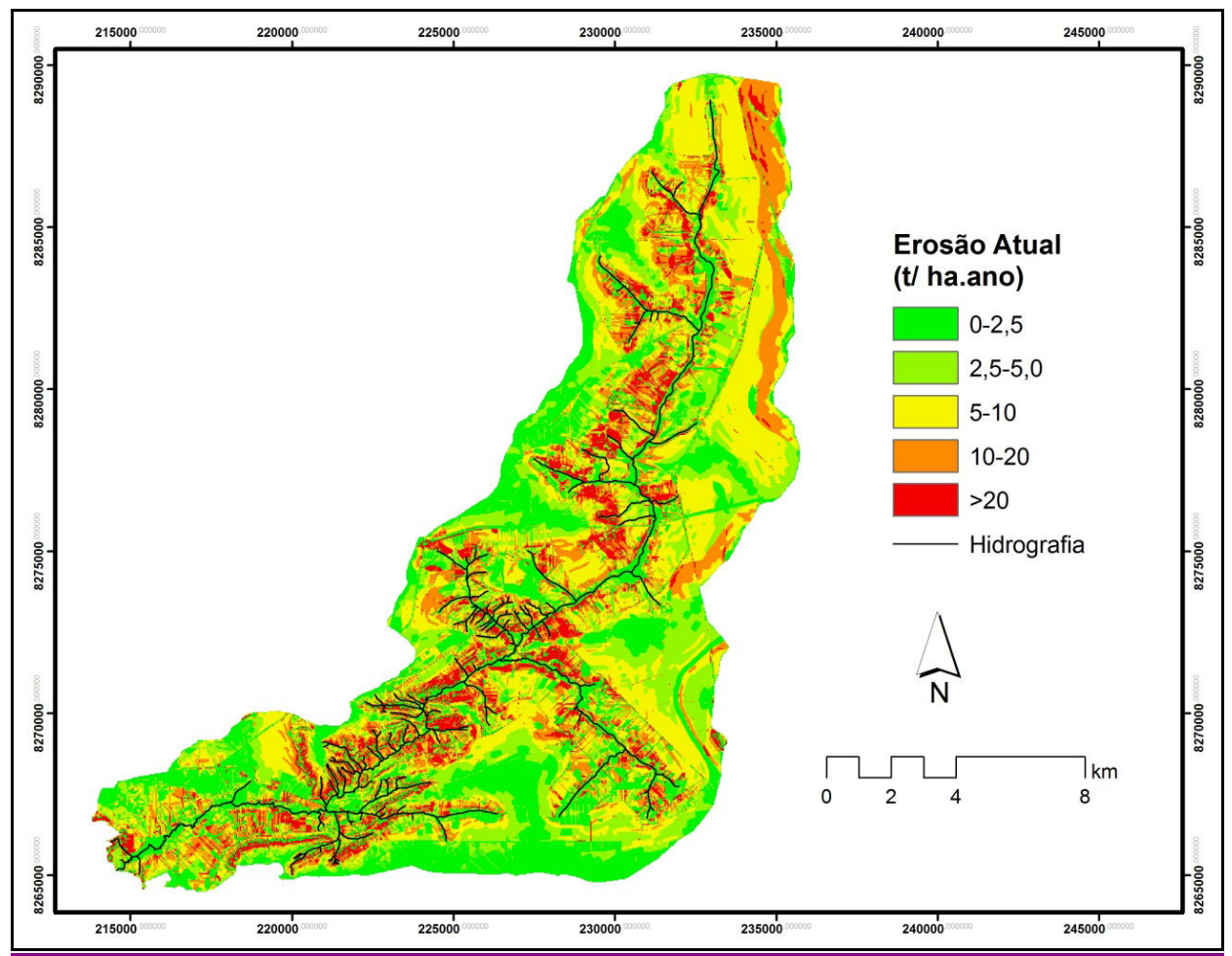

Figura 3. 3 - Perda de solo atual na bacia do ribeirão Pipiripau. Fonte: CHAVES (2012, não publicado).

\subsection{TRANSPORTE DE FÓSFORO}

Apesar de o fósforo (P) ser um elemento relativamente abundante no ambiente, ele nunca é 
encontrado em estado livre na natureza. Ele ocorre principalmente sob a forma de fosfatos, $\left(\mathrm{PO}_{4}{ }^{3-}, \mathrm{HPO}_{4}{ }^{2-}, \mathrm{H}_{2} \mathrm{PO}_{4}{ }^{-}\right)$, ligados a um cátion em compostos inorgânicos insolúveis, como fosfato de cálcio simples- $\mathrm{Ca}_{3}\left(\mathrm{PO}_{4}\right)_{2}$, fosfato de alumínio- $\mathrm{A} / \mathrm{PO}_{4}$, fosfato férrico- $\mathrm{FePO}_{4}$, e o fosfato misto - $\mathrm{CaF}_{2} \cdot 3 \mathrm{Ca}_{3}\left(\mathrm{PO}_{4}\right)_{2}$ ou como componente de moléculas orgânicas (SAWYER; McCARTY; PARKIN, 2003).

De acordo com a lei de Liebig (Lei do Mínimo), o crescimento de um organismo é limitado por aquele nutriente que se encontra em menor proporção no ambiente, em relação à necessidade do organismo. Em baixas concentrações do nutriente limitante, o crescimento populacional é baixo. Com a elevação da concentracão do nutriente limitante, o crescimento populacional também aumenta (VON SPERLING, 2007).

O fósforo é um nutriente limitante e essencial à vida. Sua escassez é devida aos seguintes fatores principais (VON SPERLING, 2007):

- Os minerais fosfatados existentes não são muito solúveis;

- O fósforo não existe na forma gasosa. Diferentemente do carbono e do nitrogênio, não há uma fonte atmosférica gasosa;

- O fosfato tende a se unir fortemente a partículas finamente granuladas. A sedimentação dessas partículas, juntamente com a sedimentação de partículas orgânicas contendo fósforo, serve para remover o fósforo da água, transportando-o para o sedimento de fundo. Nos casos em que a água em contato com o sedimento contém oxigênio, o fósforo torna-se quimicamente ligado.

O teor de fósforo inorgânico nos solos é muito maior que o de fósforo orgânico. A forma orgânica de $\mathrm{P}$ inclui relativamente os fosfolípidos lábeis, ácidos nucleicos, inositóis, ácidos fúlvicos e ácidos húmicos. Ela pode representar de 20 a 70\% do fósforo total da camada arável do solo. Logicamente, a sua contribuição será tanto maior quanto maior for o teor de matéria orgânica do solo (NOVAIS et al., 2007). O fósforo inorgânico, por sua vez, é extremamente reativo, e existe na litosfera em mais de 150 formas diferentes de minerais.

Os solos agrícolas podem apresentar de 100 a $2500 \mathrm{~kg} / \mathrm{ha}$ de fósforo total na camada arável. Todavia, qualquer que seja a natureza do solo, a concentração de fósforo em solução é extremamente baixa, normalmente entre 0,1 e $1,0 \mathrm{~kg} / \mathrm{ha}$, dada a elevada 
tendência de remoção do fósforo da solução, tanto por precipitação quanto por adsorção (NOVAIS et al., 2007).

Lindsay (1979) sugere que, para valores de $\mathrm{pH}$ abaixo de 5,8, são os fosfatos de $\mathrm{Al}$ e $\mathrm{Fe}$ que controlam a concentração de $\mathrm{P}$ no solo e, acima desse valor, fosfatos de $\mathrm{Ca}$ e $\mathrm{Mg}$. Entretanto, fosfatos de $\mathrm{Al}, \mathrm{Fe}, \mathrm{Ca}$ e $\mathrm{Mg}$ podem coexistir sobre uma ampla faixa de $\mathrm{pH}$ do solo.

Em função disso, quanto mais ácido e maior o teor de argila do solo, e, principalmente, quanto maior o predomínio de óxidos de ferro e de alumínio na fração argila, maior será a capacidade de fixação de $\mathrm{P}$ do solo. Em termos práticos, o teor de argila é uma característica a ser considerada, pois apresenta elevada correlação com a fixação de fosfato por solos sob vegetação de cerrado (Lopes, 1984), dada a grande ocorrência de óxidos de alumínio e ferro na fração argila desses solos.

Devido à forte capacidade de fixação do fósforo, a liberação de fósforo em uma bacia hidrográfica depende do tipo de solo, da declividade do terreno, do cultivo e da estrutura das chuvas. A mobilidade do fósforo está freqüentemente ligada aos processos de erosão superficial, que carregam partículas sólidas e nutrientes naturais ou provenientes de fertilizantes, empobrecendo ou mesmo destruindo o solo e degradando os corpos d'água (COPE, 2008).

Segundo Sharpley (1985), o transporte de fósforo em superfície ocorre através da ação da água da chuva, pela desagregação e dissolução das partículas do solo e dos resíduos vegetais. Há uma interação com uma fina camada da superfície do solo, antes de transformar-se em escoamento superficial. Os solos arenosos e com baixo teor de matéria orgânica são mais facilmente desagregados pelo impacto da gota da chuva, que promove o selamento da camada superficial do solo, potencializando o escoamento superficial (Reichert, 1988). Nessa etapa, o teor de umidade do solo, no momento da precipitação, é determinante para a desagregação de suas partículas.

McDowell et al. (2001) relatam que a quantidade de fósforo que chega até os cursos d'água pode ser considerada como função da quantidade de $\mathrm{P}$ no solo e das condições hidrológicas da bacia. Se quisermos mitigar a perda de fósforo do solo para as águas, precisamos entender a dinâmica de $\mathrm{P}$ no solo e sua interação com a hidrologia do solo 
(PELLEGRINI, 2005).

Silva et al. (2005) afirmam que as maiores perdas de P acompanham as perdas de carbono orgânico (CO) e as perdas de solo, o que se deve em parte ao $\mathrm{P}$ orgânico e pelo fato desse nutriente ser preferencialmente perdido por erosão e transportado adsorvido à fração coloidal mineral.

De acordo com Sharpley et al. (1992) as quantidades e as formas de fósforo transferidas variam de evento para evento pluviométrico, por causa das variações sazonais das chuvas em intensidade e duração, do intervalo de tempo entre os eventos, do estádio de cultivo e do grau de cobertura vegetal do solo, entre outros fatores.

A intensidade e duração da chuva influenciam a magnitude da descarga líquida e da concentração de sedimento em suspensão no deflúvio superficial (PELLEGRINI, 2005). Dessa forma, há uma relação direta entre o aumento dessas variáveis que, por sua vez, se relacionam diretamente com o aumento das transferências de fósforo (QUINTON et al., 2001). Esses autores concluíram que as chuvas de baixa intensidade são tão ou mais importantes que as de alta intensidade para as transferências de fósforo, considerando a freqüência e o número de cada uma delas.

Lombardi e Moldenhauer (1992) citam experiências na África do $\mathrm{Sul}_{2}$ onde 25,4 $\mathrm{mm} \mathrm{h}^{-1}$ seriam chuvas consideradas com energia erosiva suficiente para provocar transporte de solo, e, por extensão, o fósforo reativo contido nele.

McDOWELL et al. (2001), por sua vez, reportaram que os sedimentos erodidos das áreas agrícolas contêm maior percentagem de partículas finas comparados com o solo de origem, isso porque a energia cinética dessas partículas é maior quanto menor for o diâmetro da partícula.

Devido a essa seletividade do processo erosivo, o conteúdo de fósforo e a reatividade do sedimento são maiores que o observado no solo original (SHARPLEY, 1985). Pinheiro et al. (2010) em seu trabalho, concluíram que o sedimento transportado pela erosão apresentou as seguintes taxas de enriquecimento: 1,76 vezes mais $\mathrm{P} ; 1,27$ mais $\mathrm{K} ; 4,48$ mais $\mathrm{Ca}$ e 3,14 mais $\mathrm{Mg}$ do que no solo original.

Nos agroecossistemas, o movimento da água sobre o solo é potencializado e as 
transferências de sedimento e de fósforo para os corpos d'água são qualitativa e quantitativamente superiores aos provenientes de áreas cobertas por florestas. Essas modificações interferem na dinâmica do fósforo na água resultando, na maioria dos casos, em concentrações superiores ao suporte físico, químico e biológico desses recursos hídricos (PELEGRINI, 2005).

Nos ecossistemas naturais, como as microbacias florestadas, as taxas de erosão são similares àquelas fornecidas pelo intemperismo, que é determinado pela ação dos fatores de formação do solo (PELEGRINI, 2005). Nesses casos, as transferências de sedimento durante as enxurradas aos corpos d'água são mínimas e o aporte de fósforo ocorre de maneira sincronizada às necessidades das populações de macro e microrganismos aquáticos. Isso se deve às condições do ambiente natural, o qual propicia maior infiltração da água, redução do impacto da gota da chuva, redução do escoamento superficial e maior atividade de reciclagem da água e do fósforo (PELEGRINI, 2005).

Sobre a questão de perdas de fósforo no solo, SHARPLEY et al. (1994) destacaram a diferença entre as duas formas possíveis de fósforo. A primeira é o P dissolvido na água de enxurrada, composta principalmente de ortofosfato, que é prontamente disponível para absorção pelas algas. A segunda forma é o $\mathrm{P}$ adsorvido às partículas de solo (principalmente na forma inorgânica particulada, que compreende minerais fosfatados, ortofosfato adsorvido e fosfato complexado em sólidos) e na matéria orgânica, e é uma fonte de $\mathrm{P}$ de longo prazo no corpo de água em que for depositado. Das duas formas de transporte de $\mathrm{P}$, a segunda é dominante.

Olivera (2007) relatou que na água da enxurrada não foram registradas perdas de fósforo devido aos baixos valores desse elemento no solo, pelo fato de o mesmo estar adsorvido aos colóides do solo. O maior transporte se deu nas frações de argila e silte, implicando em maiores perdas no sedimento carreado pela enxurrada. Como aquele elemento químico é fortemente adsorvido pelas argilas, uma maior proporção é transportada na forma adsorvida juntamente com as partículas do solo, fato que pode explicar a não ocorrência do elemento em suspensão na água da enxurrada. As perdas de nutrientes no sedimento variaram entre 96 a 99\% do total de perdas no período estudado.

BOSSCHE et al. (2000) por sua vez, observaram que o P ligado ao sedimento representava 
mais de $80 \%$ do total de $\mathrm{P}$ exportado por enxurrada. O P no sedimento inclui as formas adsorvidas às partículas de solo e de máteria orgânica, arrastadas por erosão, representando entre 75 e $95 \%$ do P transportado em um solo arado (GALDOS, 2003).

Reckhow, Beaulac e Simpson (1980) realizaram uma extensa pesquisa na literatura referente a coeficientes de exportação de fósforo para diversas bacias da América do Norte $_{2}$ e apresentaram o valor médio de coeficiente de exportação de P, em florestas, de $0,21 \mathrm{Kg} / \mathrm{ha} / \mathrm{ano}$. No caso das pastagens, o valor médio compilado foi de $0,81 \mathrm{Kg} / \mathrm{ha} / \mathrm{ano}$. Já para áreas de agricultura intensiva e não intensiva, os valores médios de coeficiente de exportação de fósforo foram de 2,20 e $0,7 \mathrm{~kg} / \mathrm{ha} / \mathrm{ano}$, respectivamente.

\subsection{FÓSFORO NA ÁGUA}

Apesar de o fósforo ser naturalmente escasso no ambiente, em função de sua estrutura química particular (Lei de Oddo-Harkin), muitas atividades antrópicas transportam o fósforo para águas naturais. Essas atividades podem contribuir para uma elevação dos teores de fósforo no meio aquático.

O nitrogênio e fósforo são essenciais para o crescimento de algas e cianobactérias na água, e a quantidade desses elementos é normalmente o fator que limita suas taxas de crescimento. Onde ambos, nitrogênio e fósforo, são abundantes, florações de algas ocorrem, o que pode produzir uma série de condições danosas nos cursos d'água, particularmente os lênticos.

Experiências têm demonstrado que as florações de algas não ocorrem quando nitrogênio ou fósforo ou ambos, estão presentes em quantidades muito limitadas. Segundo Leopold (1970), um lago oligotrófico é definido como aquele com menos de 10 microgramas por litro de fósforo total em uma média anual, e lagos eutróficos são queles com uma concentração de mais de 20 microgramas por litro. Já lagos mesotróficos são intermediários, com concentração de fósforo total entre 10 e 20 microgramas por litro.

Estudos realizados em corpos d'água não poluídos indicam que um aumento de $0,01 \mathrm{mg} / \mathrm{L}$ na concentração do P - dissolvido já é suficiente para estimular o crescimento abundante de algas (LITKE, 1999), enquanto que níveis de concentração de P - dissolvido em corpos d'água em torno de $0,2-0,3 \mathrm{mg} / \mathrm{L}$ representam um sério risco de eutrofização 
(MAINSTONE ; PARR, 2002).

Em trabalho recente promovido pela indústria de fertilizantes brasileira, chegou-se a conclusão que, em média, somente $54 \%$ do fosfato aplicado como fertilizante químico era aproveitado pelas plantas, enquanto que os $46 \%$ restantes eram perdidos para o ambiente (Cunha et al., 2010). Desse montante, não foi levado em conta todo o restante de fontes fosfatadas, como os adubos orgânicos ou ainda o manejo de solo utilizando-se a adubação verde, que permite a biodisponibilização na superfície do solo de fósforo que se encontra em profundidade no perfil do solo (GEBLER et al., 2012).

Tal consideração é importante, uma vez que para culturas anuais como milho ou soja, a exigência de nutriente agrícola pode variar entre 25 a $45 \mathrm{~kg} \mathrm{ha}^{-1} \mathrm{ano}^{-1}$ de $\mathrm{P}$, enquanto que, para haver a eutrofização acelerada de rios e lagos, bastam volumes entre 1 a $2 \mathrm{~kg} \mathrm{ha}^{-1}$ ano $^{-}$ ${ }^{1}$ de $\mathrm{P}$ (GEBLER et al., 2012).

\subsection{PEGADA HÍDRICA}

Água doce de qualidade adequada não é somente um pré- requisito para a sociedade humana, mas também para o ecossistema natural, que realiza funções essenciais para a existência humana e da vida na terra (LEENES; HOEKSTRA, 2008). Entretanto, o aumento e a diversificação dos usos múltiplos, o extenso grau de urbanização e o aumento populacional resultaram em uma multiplicidade de impactos nos recursos hídricos (TUNDISI, 2003).

Os impactos em questão têm exigido, de acordo com o mesmo autor, diferentes tipos de avaliação, novas tecnologias de monitoramento e avanços tecnológicos no tratamento e gestão das águas. Esta última tem fundamental importância no futuro dos recursos hídricos, pois os cenários de uso aumentando e excessivo estão relacionados com uma continuidade das políticas no uso e gestão pouco evoluída conceitual e tecnologicamente.

Diante disso, tem sido proposta uma nova visão para o gerenciamento dos recursos hídricos. Essa nova visão se preocupa não só com a alocação de água para a manutenção das atividades humanas e ambientais, mas também com a origem da água alocada, com a quantidade disponível para as culturas e os ecossistemas e a quantidade necessária para 
diluir a poluição causada por essas atividades (ZAFFANI, et al., 2011).

A pegada hídrica $(\mathrm{PH})$ é um indicador de consumo de água doce que contabiliza não somente o uso direto de água de um consumidor, produto, ou processo, mas também o uso indireto de água. É considerada um indicador global da apropriação dos recursos da água doce, ao lado do tradicional e limitado conceito de uso de água. A pegada hídrica é um indicador multidimensional, demonstrando o volume de água consumida pela fonte e o volume poluído pelo tipo de poluição (HOEKSTRA et al., 2011).

No Brasil, a pegada hídrica começou a ser discutida por gestores de água a partir de uma reunião proposta em conjunto pela TNC e WWF, no âmbito da iniciativa Alliance for Water Stewardship (AWS). A partir disso, organizações internacionais sediadas no Brasil foram os atores que iniciaram a popularização ou disseminação da temática da pegada hídrica no país (EMPINOTTI, 2012).

A pegada hídrica considera em seu cálculo não só o volume de água consumido a partir de diversas fontes, como a água superficial e subterrânea (água azul) e a água da chuva armazenada no solo (água verde), mas também a quantidade de água poluída durante o processo produtivo em um determinado local e período (água cinza) (HOEKSTRA, 2008).

Estima-se que a pegada hídrica global seja de $7.450 \mathrm{~km}^{3}$ /ano, o que representa em média, $1.240 \mathrm{~m}^{3}$ /ano per capita (HOEKSTRA; CHAPAGAIN, 2007). De acordo com os autores, a Índia é o país com a maior pegada hídrica no mundo, com um total de $987 \mathrm{~km}^{3} /$ ano. Entretanto, enquanto a Índia contribui com $17 \%$ da população global, as pessoas na Índia contribuem somente com $13 \%$ da pegada hídrica global. Em uma base relativa, é a população dos Estados Unidos que tem a maior pegada hídrica, com $2.480 \mathrm{~m}^{3} /$ ano per capita, seguida pelas pessoas nos países do sul da Europa como a Grécia, Itália e Espanha, com a pegada hídrica entre 2.300 e $2.400 \mathrm{~m}^{3} /$ ano, per capita. Altas pegadas hídricas também podem ser encontradas na Malásia e na Tailândia. Por outro lado, os chineses têm uma pegada hídrica relativamente baixa, de aproximadamente $700 \mathrm{~m}^{3} /$ ano per capita.

Alguns pesquisadores têm estimado a pegada hídrica em diferentes contextos. Os diversos estudos de pegada hídrica que foram realizados até agora podem ser categorizados como: estudos globais, nacionais, regionais e de bacias hidrográficas, estudos de produtos gerais e 
de empresas (HOEKSTRA et al., 2011). Entre eles estão os seguintes:

- Chapagain e Hoekstra (2011), que fizeram uma avaliação global das pegadas hídricas verde, azul e cinza do arroz e concluíram que a pegada hídrica global da produção de arroz é de $784 \mathrm{~km}^{3} /$ ano, sendo a pegada hídrica verde responsável por $48 \%$, a azul $44 \%$ e a cinza por $8 \%$.

- Hoekstra e Mekonnen (2012) estimaram a pegada hídrica por nação para ambas as perspectivas de produção e consumo. A média anual global da pegada hídrica no período entre 1996-2005 foi de 9,087 $\mathrm{Km}^{3} /$ ano (74\% verde, $11 \%$ azul e $15 \%$ cinza). A produção agrícola contribuiu com $92 \%$.

- Steen - Olsen et al. (2012) avaliaram três tipos de pegadas ambientais, entre elas a pegada hídrica, para os estados membros da União Européia e encontraram um valor médio de consumo de água superficial e subterrânea de $179 \mathrm{~m}^{3}$.

- Zeng et al. (2012) avaliaram a pegada hídrica da bacia hidrográfica Heihe no noroeste da China. Os resultados por eles encontrados mostraram que a pegada hídrica para essa bacia foi de 1.768 milhões $\mathrm{m}^{3}$ por ano, sendo que a produção agrícola foi a maior consumidora de água, respondendo por $96 \%$ da pegada hídrica. Os $4 \%$ restantes foram para os setores industrial e doméstico. Esses resultados indicaram uma pegada hídrica não sustentável.

- Zaffani et al. (2011) estudaram a poluição da drenagem urbana relacionada com a pegada hídrica cinza em três pontos de monitoramento da cidade de São Carlos. Eles encontraram o valor médio de pegada hídrica cinza para o parâmetro sólidos totais 3,$40 ; 1,64$ e $1,71(\mathrm{mg} / \mathrm{h} / \mathrm{ha})$, para o parâmetro fosfatos totais 66,$21 ; 17,95 \mathrm{e}$ 20,84 (mg/h/ha) e para o parâmetro DBO 9,79; 7,05 e 6,73 (mg/h/ha)

\subsection{TIPOS DE PEGADA HÍDRICA}

\subsubsection{Pegada hídrica azul}

A pegada hídrica azul refere-se ao consumo de recursos de água azul (superficial e 
subterrânea) ao longo da cadeia de abastecimento de um produto ou processo. Consumo refere-se à perda de água disponível na superfície do corpo d'água de uma bacia. A perda ocorre quando a água evapora, retorna a outra bacia ou ao mar ou é incorporada em um produto (HOEKSTRA et al., 2011).

Hoekstra et al., (2011) descreve a pegada azul como um indicador do uso consuntivo da água azul (doce de superfície ou subterrânea). Ao se usar o termo "uso consuntivo da água", esse se refere a um dos quatro casos abaixo:

a) Quando a água evapora;

b) Quando a água é incorporada ao produto;

c) Quando a água não retorna à mesma bacia de captação, por exemplo, e sim para outra bacia de captação, ou para o oceano; e

d) Quando a água não retorna no mesmo período por exemplo, quando é retirada em um período de seca e retorna em um período de chuvas.

O "uso consuntivo da água" não significa que a água desaparece, pois a água permanecerá dentro do ciclo e retornará sempre para algum lugar. A pegada hídrica azul mede a quantidade de água disponível que é consumida em um determinado período (em outras palavras, que não retorna imediatamente para a mesma bacia). Dessa forma, ela fornece uma medição da quantidade de água azul consumida pelo homem. O restante, ou seja, os fluxos de água subterrânea e de água de superfície não utilizados para atividades humanas são utilizados para manter os ecossistemas que dependem dos fluxos de água subterrânea e de superfície (HOEKSTRA et al., 2011). A pegada hídrica azul é calculada da seguinte forma:

$$
\begin{gathered}
\text { PHa = Evaporação da água azul + Incorporação da água azul + Fluxo de retorno } \\
\text { perdido }
\end{gathered}
$$

A unidade da pegada hídrica azul de um processo é o volume de água por unidade de tempo (dia, mês ou ano). Quando dividida pela quantidade do produto resultante do processo, a pegada hídrica do processo também pode ser expressa em termos de volume de água por unidade de produto.

\subsubsection{Pegada hídrica verde}

A pegada hídrica verde refere-se ao consumo de recursos de água verde (água de chuva, 
desde que não escoe). A água verde refere-se à precipitação na terra que não é escoada ou não repõe a água subterrânea, mas é armazenada no solo ou permanece temporariamente no solo ou na vegetação. Essa parte da precipitação acaba evaporando ou transpirando por meio das plantas. A água verde pode ser produtiva para o crescimento de culturas, mas nem toda água verde pode ser absorvida pelas culturas, pois sempre haverá evaporação do solo e porque nem todas as áreas e nem todos os períodos do ano são adequados para o crescimento de culturas (HOEKSTRA et al., 2011).

A pegada hídrica verde consiste no volume da água da chuva consumido durante o processo de produção vegetal. A fórmula para calcular a pegada hídrica verde é a seguinte:

$$
\text { PHv = Evaporação da água verde + incorporação da água verde }
$$

\subsubsection{Pegada hídrica cinza}

A pegada hídrica cinza diz respeito à poluição hídrica ${ }_{2}$ e é definida como o volume de água doce necessário para assimilar a carga de poluentes, consideradas as concentrações naturais de referência e os padrões de qualidade de água existentes. $\mathrm{O}$ conceito de pegada hídrica cinza surgiu ao reconhecer que o tamanho da poluição da água pode ser expresso de acordo com o volume de água necessário para diluir os poluentes de tal forma que se tornem inócuos (HOEKSTRA et al., 2011).

A ideia de expressar a poluição da água em termos de volume de água necessário para diluir resíduos não é recente. Hoekstra et al., (2011) sugeriram, como uma regra de ouro, contar com um fator de diluição equivalente a 10 a 50 vezes a concentração de águas residuais.

Chapagain et al. (2006) propuseram que o fator de diluição seja de acordo com o tipo de poluente e que se deve utilizar o padrão de qualidade da água em seu estado natural para um determinado poluente como critério para quantificar a necessidade de diluição.

Nesse sentido, a pegada hídrica cinza é calculada dividindo a carga de poluente $(L$, em massa/tempo) pela diferença entre o padrão de qualidade da água em seu estado natural para aquele poluente (a concentração máxima aceitável $c_{\max }$, em massa/volume), e sua concentração natural no corpo d'água receptor ( $c_{\text {nat }}$, em massa/volume) (HOEKSTRA et al., 2011), ou seja: 


$$
\mathrm{PHc}=\mathrm{L} /\left(\mathrm{c}_{\max }-\mathrm{c}_{\text {nat }}\right)
$$

Pode-se questionar o motivo de a referência ser a concentração natural e não a concentração real no corpo d'água receptor. A explicação para isso é que a pegada hídrica cinza é um indicador da capacidade de assimilação consumida do corpo hídrico receptor. A sua capacidade de assimilação depende da diferença entre a concentração máxima permitida e a concentração natural de uma substância.

Se comparássemos a concentração máxima permitida com a concentração real de uma substância dissolvida na água, consideraríamos a capacidade de assimilação remanescente, que, obviamente, muda constantemente, como uma função do nível real de poluição em um determinado momento (HOEKSTRA et al., 2011).

Uma pegada hídrica cinza maior que zero não significa, automaticamente, que os padrões de qualidade da água em seu estado natural foram desrespeitados, mas mostra apenas que parte da capacidade de assimilação já foi utilizada. Enquanto o valor da pegada hídrica cinza for menor do que o fluxo do rio, ou o fluxo de águas subterrâneas existentes, ainda há água suficiente para diluir os poluentes.

Quando, entretanto, a pegada hídrica cinza calculada é igual ao fluxo de água, a concentração resultante estará exatamente nos limites do padrão de qualidade de água. Quando o efluente contém uma carga muito alta de substâncias químicas, pode acontecer que a pegada hídrica cinza calculada inclusive exceda a vazão do rio ou o fluxo de águas subterrâneas. Nesse caso, a poluição vai além da capacidade de assimilação do corpo d'água receptor (HOEKSTRA et al.,. 2011).

\subsection{AVALIAÇÃO DA PEGADA HÍDRICA}

A avaliação da pegada hídrica refere-se a uma gama completa de atividades, dentre as quais estão: (i) quantificar e localizar a pegada hídrica de um processo, produto, produtor ou consumidor, ou quantificar no espaço e no tempo a pegada hídrica em uma determinada área geográfica; (ii) avaliar a sustentabilidade ambiental, social e econômica dessa pegada hídrica; e (iii) formular uma resposta estratégica (HOEKSTRA et al., 2011).

Por considerar que os recursos de água doce do mundo são limitados, avaliar pegadas hídricas se torna um indicador muito útil, uma vez que mostra quando, onde e como os 
consumidores, produtores, processos e produtos individuais demandam esse recurso limitado. A avaliação é uma ferramenta útil para quantificar e localizar as pegadas hídricas, para avaliar se elas são sustentáveis ou não e para identificar opções para reduzi-las onde for necessário.

\subsubsection{Limitações da avaliação da pegada hídrica}

Por ser a pegada hídrica um conceito relativamente novo e a sua avaliação uma nova ferramenta, ocorrem algumas limitações nos procedimentos e métodos da sua avaliação.

Hoekstra et al. (2011) deixam claro que a pegada hídrica é apenas um indicador importante dentro da ampla abrangência do tema que envolve a alocação e o uso sustentável, justo e eficiente dos recursos naturais. Obviamente, ela precisa ser complementada com vários outros indicadores relevantes, para que ocorra o entendimento integrado. De modo semelhante, a avaliação da pegada hídrica não é nada mais do que uma ferramenta que facilita o entendimento das complexas relações entre as sociedades e os ambientes onde vivem. O foco da avaliação é o uso dos recursos de água doce considerando que se trata de um recurso limitado.

Seixas (2011) por sua vez, sintetizou as principais limitações da avaliação da pegada hídrica, descritas nos seguintes pontos abaixo:

1 - A avaliação da pegada hídrica concentra-se essencialmente em analisar o uso de água doce, tendo em conta os recursos limitados desse tipo de água, não abordando outros temas ambientais como as alterações climáticas, a depleção de minerais, fragmentação de habitats, limitada disponibilidade de terra ou a degradação do solo, nem sociais ou econômicos como a pobreza, emprego e bem-estar. A avaliação da pegada hídrica dá ênfase às questões ambientais, sociais e econômicas na medida em que o uso dos recursos hídricos afecta a biodiversidade, saúde, assistência social ou a distribuição justa e equitativa deste recurso. É necessário reconhecer que a redução da pegada hídrica da humanidade é apenas um desafio para ser visto em um contexto muito mais amplo e em um vasto leque de outros desafios.

2 - A avaliação da pegada hídrica aborda a problemática da escassez de água doce e da sua poluição, porém não tem em conta a questão das enchentes assim como a 
problemática da escassa acessibilidade de certas populações à água potável, uma vez que esse não é um problema de escassez de água, mas sim uma questão de pobreza. Além disso, a pegada hídrica refere-se à água doce, e não ao uso e poluição da água do mar.

No caso da pegada hídrica cinza, uma limitação em sua avaliação são as fontes de dados. Embora os padrões de qualidade da água em seu estado natural sejam contemplados nas legislações nacional ou estadual, ou precisem ser formulados por bacia e/ou corpo d'água no âmbito da legislação nacional ou através de um acordo regional, não existem padrões para todas as substâncias e todos os lugares. Para esse caso, é importante que existam orientações que recomendem quais são os melhores valores padrão que devem ser utilizados (HOEKSTRA et al., 2011).

Outra dificuldade em relação à avaliação da pegada hídrica cinza está na quantificação da carga poluente que chega a um corpo hídrico. Não existe um procedimento geral para quantificar os diversos poluentes que existem, sendo necessária, muitas vezes, a realização de aprofundamento teórico e experimentos demorados, o que dificulta sua aplicação por muitos gestores ambientais, que amiúde precisam de respostas imediatas para o processo de tomada de decisão.

\section{MATERIAIS E MÉTODOS}

\subsection{LOCALIZAÇÃO E CARACTERIZAÇÃO DA ÁREA DE ESTUDO}

O estudo foi realizado na Bacia do Ribeirão Pipiripau, localizada no nordeste do Distrito Federal $_{2}$ na divisa com o município de Formosa/GO, com uma área total de 23.527 hectares (Figura 4.1). A maior parte da área da bacia localiza-se no Distrito Federal $(90,3 \%)$, sendo que a região sendo que a região que abriga a nascente do curso principal localiza-se no estado de Goiás (BRASIL, 2010). 


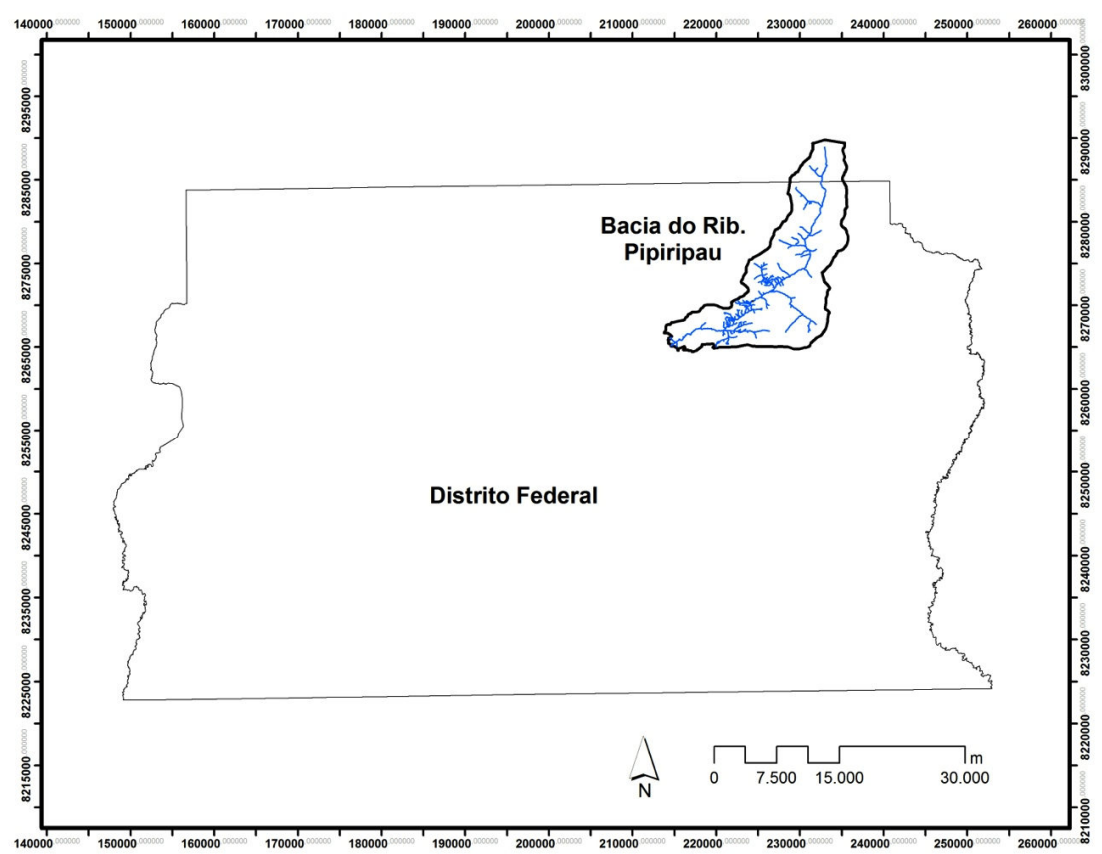

Figura 4. 1 - Localização da Bacia hidrográfcia do ribeirão Pipiripau. Fonte: Chaves (2012, não publicado).

A bacia abrange os Núcleos Rurais Pipiripau e Taquara, parte da área rural da cidade de Planaltina, o Núcleo Santos Dumont e a área do entorno do Vale do Amanhecer (CAESB, 2001). Devido ao grande crescimento populacional observado nos últimos anos, o bairro de Arapoanga, em Planaltina também estendeu parte de seu território para dentro da área da bacia (BRASIL, 2010, Figura 4.2).

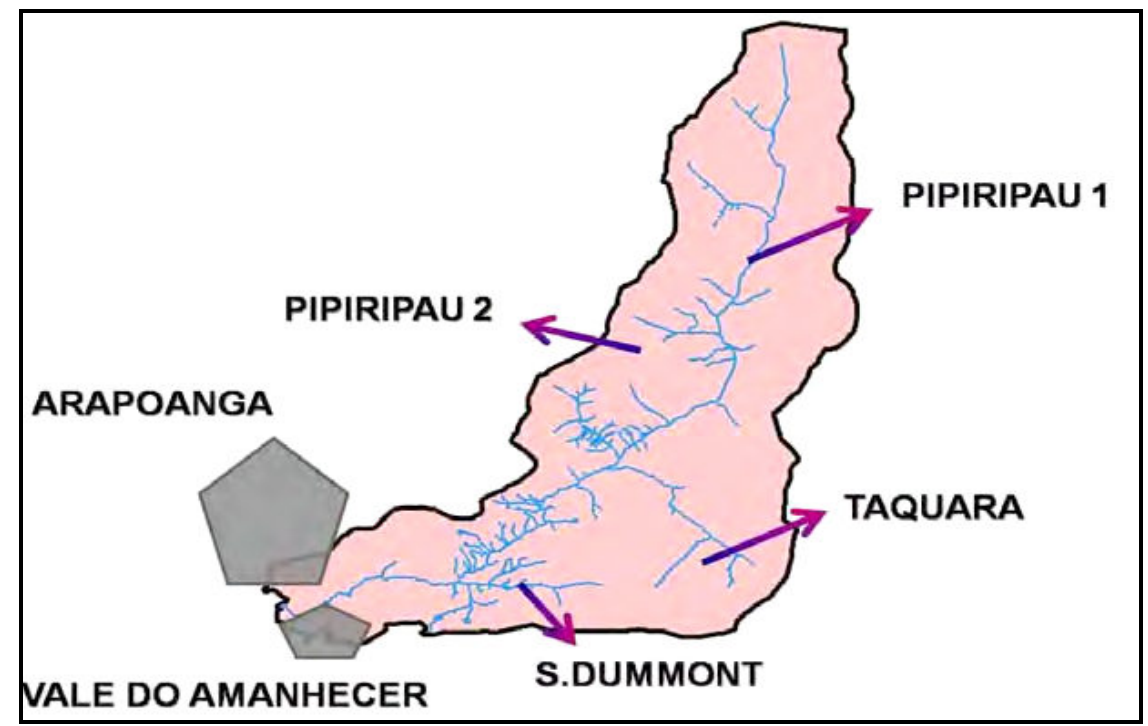

Figura 4. 2 - Setorização da bacia e localização dos núcleos urbanos. Fonte: BRASIL (2010).

Estima-se que a população rural da Bacia Hidrográfica do Ribeirão Pipiripau atual seja de aproximadamente 3.100 habitantes (HGeo, 2001). 
A Bacia do Pipiripau está inserida na área nuclear do Bioma Cerrado. Os tipos de vegetação com maior representatividade são as matas de galeria e cerrados strictu sensu e em menor escala, os campos, os campos murunduns e os cerradões (CAESB, 2001).

Os usos antrópicos do solo representam $68,04 \%$ da área total da bacia, enquanto que a vegetação nativa está presente em apenas $31,96 \%$ da área. A principal categoria de uso e ocupação do solo corresponde à agricultura extensiva, predominando o plantio de soja e milho, seguido pelas pastagens e pelas áreas agrícolas, que são destinadas em sua grande maioria ao plantio de produtos hortifrutigranjeiros (Tabela 4.1, Figura 4.3). Nas zonas agrícolas podem ser encontrados galpões para a criação de suínos e aves e também para o cultivo de tomate, pimentão, maracujá e outros produtos (HGeo, 2001).

Tabela 4. 1 - Uso e ocupação do solo da bacia hidrográfica do ribeirão Pipiripau.

\begin{tabular}{cc}
\hline TIPO DE USO E & ÁREA (\%) \\
OCUPAÇÃO DO SOLO & \\
\hline Agricultura Extensiva & 43,27 \\
Campo & 3,54 \\
Cerrado & 10,68 \\
Corpos d'água & 0,13 \\
Cultura Irrigada & 4,57 \\
Mata & 4,16 \\
Pastagem & 21,46 \\
Reflorestamento & 0,57 \\
Sede e Edificações & 1,56 \\
Solo Exposto & 0,48 \\
Vegetação Alterada & 6,56 \\
Vias não Pavimentadas & 1,50 \\
Vias Pavimentadas & 0,29 \\
Áreas Urbanas & 1,19 \\
\hline
\end{tabular}

Fonte: Adaptado de TNC (2009) 


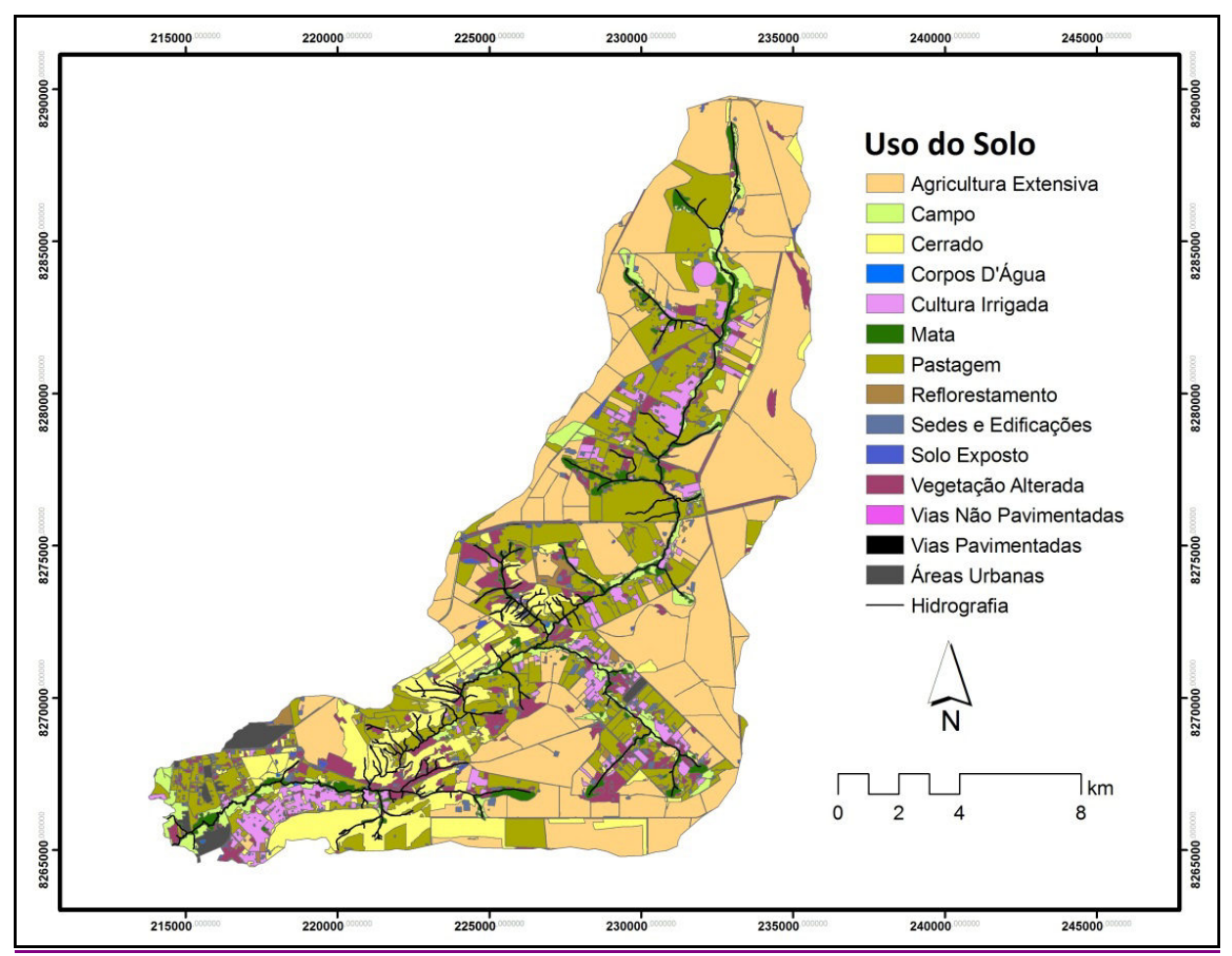

Figura 4. 3 - Mapa de uso e ocupação do solo da bacia hidrográfica do ribeirão Pipiripau. Fonte: TNC (2009).

O relevo da bacia é predominantemente plano a levemente ondulado, com uma declividade média de 5,5\% (Figura 4.4). As altitudes da região variam entre 905 e 1.225 metros (CAESB, 2001).

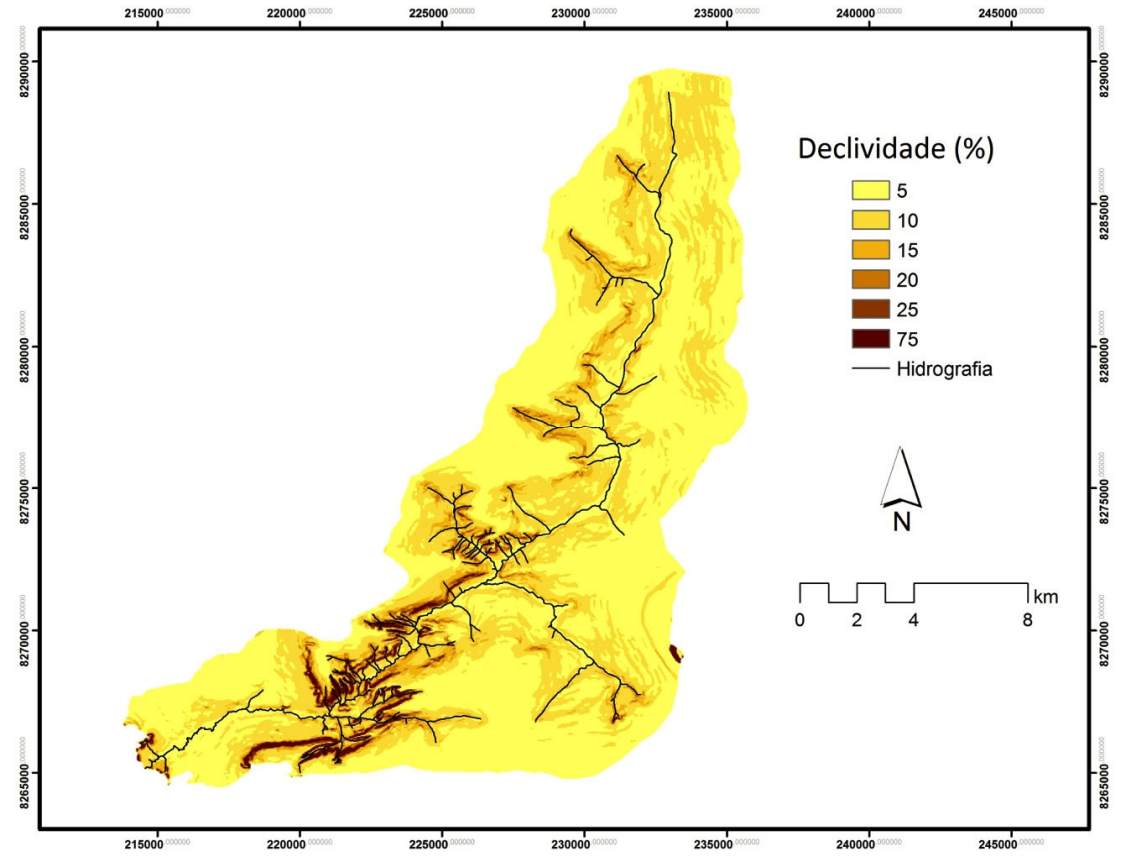

Figura 4.4 - Mapa da declividade (\%) da bacia hidrográfica do ribeirão Pipiripau. Fonte: Chaves (2012, não publicado). 
$\mathrm{Na}$ região podem ser encontradas sete classes de solo: latossolo vermelho, latossolo vermelho-amarelo, Cambissolos, neossolo quartzarênico, plintossolo pétrico, gleissolos e nitossolos vermelho (Figura 4.5).

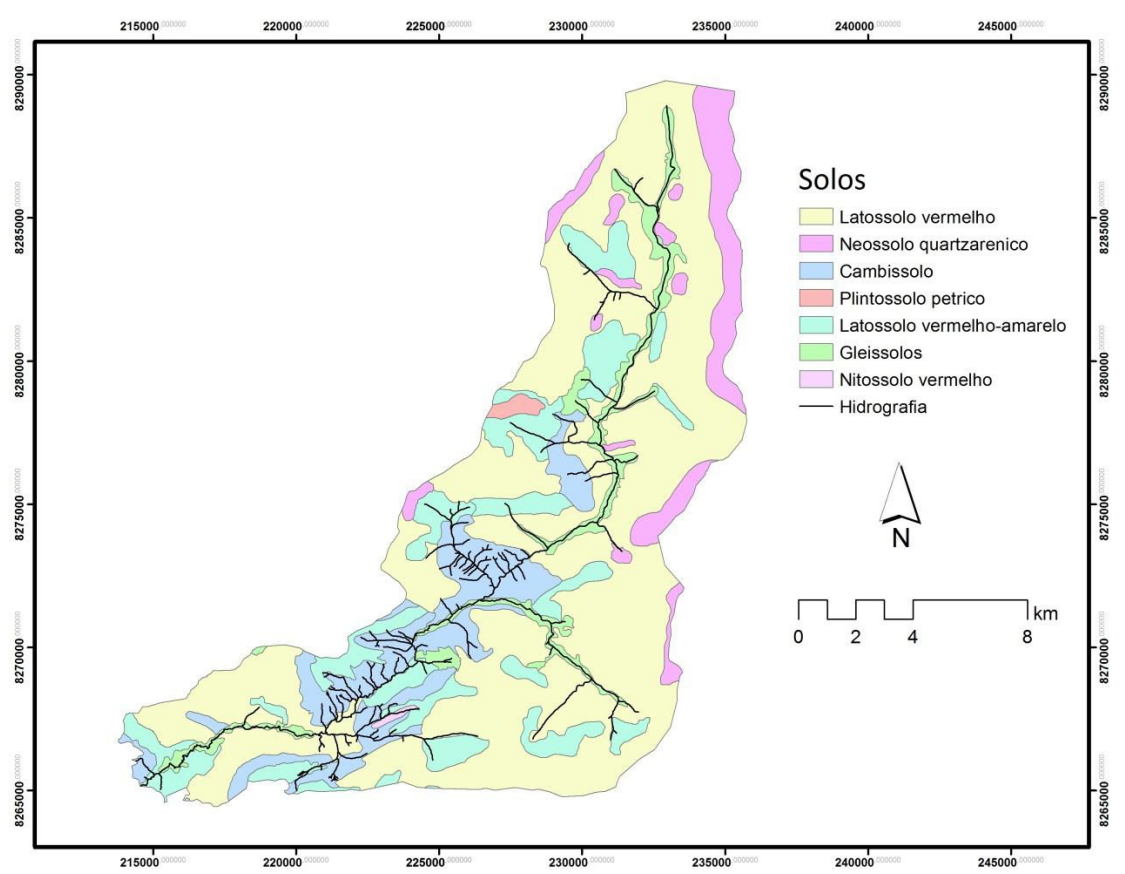

Figura 4.5 - Pedologia da bacia do ribeirão Pipiripau. Fonte: CHAVES (2012, não publicado).

A precipitação média anual na bacia é de $1.306 \mathrm{~mm}$, e o desvio-padrão é de $250 \mathrm{~mm}$, (CHAVES; PIAU, 2008). Devido ao pequeno decréscimo na precipitação média anual, o qual não chega a ser estatisticamente significativo, a série de precipitação pluvial anual pode ser considerada estacionária.

\subsection{AVALIAÇÃO DA PEGADA HÍDRICA CINZA DA BACIA}

Todo o processo de avaliação da pegada hídrica usado no presente trabalho foi baseado no Manual de Avaliação de Pegada Hídrica: Definição dos padrões globais, desenvolvido e mantido pela Water Footprint Network (WFN), em 2011.

Uma avaliação completa da pegada hídrica consiste de quatro fases distintas:

1. Definição de objetivos e escopos;

2. Contabilização da pegada hídrica;

3. Avaliação da sustentabilidade da pegada hídrica;

4. Formulação de resposta da pegada hídrica. 


\subsubsection{Definição de objetivos e escopos}

\subsubsection{Definição de objetivos}

De acordo com o proposto por Hoekstra et al. (2011) como objetivos e definições da avaliação da pegada hídrica, estão:

Item 1: Qual é a meta final da avaliação da pegada hídrica cinza?

Definição: Identificação de área crítica.

Item 2: Há um foco em uma fase particular na avaliação?

Definição: Focar na contabilização da pegada hídrica cinza e na avaliação de sua sustentabilidade;

Item 3: Qual é o âmbito de interesse? (Pegada hídrica azul, verde ou cinza)

Definição: Pegada hídrica cinza;

Item 4: Como lidar com o tempo?

Definição: Visar à avaliação anual da pegada hídrica cinza;

Item 5: Quais são os limites da área a ser avaliada?

Definição: Bacia hidrográfica;

Item 6: Qual é o campo de interesse?

Definição: Examinar onde a pegada hídrica dentro da área viola os padrões ambientais de qualidade da água.

\subsubsection{Definição de escopos}

Para o escopo da contabilização da pegada hídrica, alguns itens foram especificados:

Item 1: Considerar a pegada hídrica azul, verde e/ou cinza?

Definição: Neste trabalho foi considerada a pegada hídrica cinza com o fim de expressar a poluição da água em termos de volume poluído, podendo ela ser comparada com o consumo de água, que também é expresso como um volume.

Item 2: Qual o nível de resolução espaço-temporal? 
Definição: Pegadas hídricas podem ser avaliadas em diferentes níveis de resolução espaço-temporal (Tabela 4.2). No caso deste estudo, o nível de resolução espaçotemporal é o nível B. (HOEKSTRA et al., 2011).

Item 3: Que período de dados?

Definição: Qualquer que seja o estudo sobre pegada hídrica que esteja sendo realizado, deve-se ser explícito quanto ao período de dados utilizado, pois o período escolhido irá afetar o resultado (HOEKSTRA et al., 2011). O período de dados deste projeto é anual.

Tabela 4. 2 - Níveis de resolução espaço-temporal das pegadas hídricas.

\begin{tabular}{|c|c|c|c|c|}
\hline & $\begin{array}{l}\text { RESOLUÇÃO } \\
\text { ESPACIAL }\end{array}$ & $\begin{array}{l}\text { RESOLUÇÃO } \\
\text { TEMPORAL }\end{array}$ & $\begin{array}{l}\text { FONTE DE DADOS } \\
\text { NECESSÁRIOS NO } \\
\text { USO DA ÁGUA }\end{array}$ & $\begin{array}{c}\text { USO TÍPICO DAS } \\
\text { CONTABILIZAÇÕES }\end{array}$ \\
\hline $\begin{array}{l}\text { NÍVEL } \\
\quad A\end{array}$ & Média global & Anual & $\begin{array}{l}\text { Literatura e banco de } \\
\text { dados disponíveis no } \\
\text { consumo e poluição } \\
\text { típicos de água através } \\
\text { de produto ou processo. }\end{array}$ & $\begin{array}{c}\text { Ações de conscientização, } \\
\text { identificação preliminar } \\
\text { dos componentes que mais } \\
\text { contribuem para a pegada } \\
\text { hídrica total; } \\
\text { desenvolvimento de } \\
\text { projeções globais do } \\
\text { consumo da água. }\end{array}$ \\
\hline $\begin{array}{l}\text { NÍVEL } \\
\quad B\end{array}$ & $\begin{array}{l}\text { Bacia } \\
\text { hidrográfica } \\
\text { nacional, } \\
\text { regional ou } \\
\text { específica }\end{array}$ & $\begin{array}{l}\text { Anual ou } \\
\text { mensalmente }\end{array}$ & $\begin{array}{l}\text { Como descrito acima, } \\
\text { mas o uso de dados de } \\
\text { bacias hidrográficas } \\
\text { nacionais, regionais ou } \\
\text { específica. }\end{array}$ & $\begin{array}{l}\text { Identificação preliminar da } \\
\text { difusão e variabilidade } \\
\text { espaciais; base de } \\
\text { conhecimento para } \\
\text { identificação de áreas } \\
\text { críticas e decisões de } \\
\text { alocação de água. }\end{array}$ \\
\hline $\begin{array}{l}\text { NÍVEL } \\
\text { C }\end{array}$ & $\begin{array}{l}\text { Microbacia ou } \\
\text { área específica } \\
\text { no campo }\end{array}$ & $\begin{array}{l}\text { Mensal ou } \\
\text { diariamente }\end{array}$ & $\begin{array}{l}\text { Dados empíricos ou (se } \\
\text { não forem diretamente } \\
\text { mensuráveis) melhores } \\
\text { estimativas do consumo } \\
\text { e poluição da água, } \\
\text { especificados por local } \\
\text { e durante o ano. }\end{array}$ & $\begin{array}{l}\text { Base de conhecimento para } \\
\text { a realização de uma } \\
\text { avaliação de } \\
\text { sustentabilidade de uma } \\
\text { pegada hídrica; formulação } \\
\text { de uma estratégia para } \\
\text { reduzir a pegada hídrica e } \\
\text { os impactos locais } \\
\text { associados. }\end{array}$ \\
\hline
\end{tabular}

Fonte: HOEKSTRA et al. (2011).

Para o escopo da avaliação de sustentabilidade, a questão primária é se será tomada a perspectiva geográfica ou a perspectiva de um processo, produto, consumidor ou produtor. Para a execução deste projeto foi tomada a perspectiva geográfica, ou seja, a bacia 
hidrográfica. Dessa forma, o escopo da avaliação da sustentabilidade de uma pegada hídrica depende primeiramente da perspectiva escolhida.

A seguinte lista de verificação foi usada para o escopo da avaliação de sustentabilidade da Pegada Hídrica na bacia estudada:

Item 1: Considerar a sustentabilidade da pegada hídrica verde, azul e/ou cinza?

Definição: Sustentabilidade da pegada hídrica cinza;

Item 2: Considerar a dimensão de sustentabilidade ambiental, social e/ou econômica?

Definição: Foi considerada a dimensão de sustentabilidade ambiental. Segue mais descrições no item 4.2.5;

Item 3: Identificar somente áreas críticas ou analisar detalhadamente impactos primários e/ou secundários nessas áreas?

Definição: Somente áreas críticas foram identificadas, recomendando um detalhamento dos impactos primários e secundários a estudos posteriores.

Para o escopo da fase de formulação da resposta, novamente o tipo de pegada hídrica que está sendo avaliado entra em questão. Em se tratando do caso em tela, o tipo escolhido foi a pegada hídrica cinza. No caso da pegada hídrica cinza dentro de uma área delimitada geograficamente, a questão analisada foi: o que pode ser feito e por quem para reduzir a pegada hídrica dentro daquela área, por quanto tempo e qual o caminho? (HOEKSTRA et al., 2011).

\subsubsection{Contabilização da pegada hídrica cinza}

Para a contabilização da pegada hídrica cinza, foi utilizada a equação 4.1, descrita por Hoekstra et al. (2011).

A pegada hídrica cinza é a carga de poluente ( $L$, em massa/tempo), dividida pela diferença entre o padrão de qualidade da água em seu estado natural para aquele poluente (a concentração máxima aceitável $c_{\max }$, em massa/volume), e sua concentração natural no corpo d'água receptor ( $c_{\text {nat }}$, em massa/volume), ou seja: 


$$
\mathrm{PH}_{\text {cinza }}=\mathrm{L} /\left(\mathrm{C}_{\max }-\mathrm{C}_{\text {nat }}\right)
$$

Onde $\mathrm{PH}_{\text {cinza }}$ é a pegada hídrica cinza $\left(\mathrm{m}^{3} / \mathrm{s}\right)$; L, a carga de poluente $(\mathrm{kg} / \mathrm{ano})$; Cmax, a concentração máxima aceitável do poluente $(\mathrm{Kg} / \mathrm{L})$ e Cnat, a concentração natural do poluente no corpo d'água $(\mathrm{Kg} / \mathrm{L})$.

\subsubsection{Agrupamento das classes de uso e ocupação do solo}

Para o cálculo da carga de fósforo total (L) no curso d'água, foi necessário primeiramente realizar o agrupamento das classes do uso e ocupação do solo, no mapa de uso do solo da bacia. Neste trabalho, as classes de uso do solo (figura 4.3) foram agrupadas em três grandes principais classes: i) classe urbana, ii) classe agrícola e iii) classe de cerrado.

Esse agrupamento é basedo nas conclusões de Uttomark et al. (1974). Esses autores concluíram que quando são usadas atividades de uso do solo como base para estimar cargas de poluentes provenientes de fontes não pontuais, há pouca justificação para a delimitação do uso da terra nas bacias de drenagem além de quatro grandes categorias: urbanas, agrícolas, florestas (condição natural, em nosso caso, cerrado) e zonas úmidas. Eles indicaram ainda que os dados de exportação de nutrientes disponíveis são demasiadamente fragmentados e variáveis para justificar ainda mais a subdivisão de categorias de uso da terra.

Dessa forma, as classes de uso do solo foram agrupadas de acordo com a tabela 4.3:

Tabela 4. 3 - Agrupamento das classes de uso do solo

\begin{tabular}{cc}
\hline ÁREAS & CLASSES DE USO DO SOLO \\
\hline Agrícola & $\begin{array}{c}\text { Pastagem, Agricultura extensiva e Cultura } \\
\text { irrigada. }\end{array}$ \\
Urbana & $\begin{array}{c}\text { Solo exposto, Sedes e edificações, Áreas } \\
\text { urbanas, Vias pavimentadas e Vias não } \\
\text { pavimentadas. }\end{array}$ \\
Cerrado & $\begin{array}{c}\text { Cerrado, Vegetação alterada, Campo, Mata } \\
\text { e Reflorestamento. }\end{array}$
\end{tabular}

Fonte: autoria própria (2013). 


\subsubsection{Cálculo da carga poluente (L)}

No presente estudo, o cálculo da pegada hídrica cinza foi baseado no carregamento de fósforo total $(\mathrm{Pt})$, pela enxurrada. Supôs-se que a carga de fósforo total $(\mathrm{Pt})$ foi proveniente de fontes difusas de $\mathrm{P}$ da bacia hidrográfica do Ribeirão Pipiripau. Para o cálculo, foram usados valores de concentrações e coeficientes de exportação de fósforo toal para cada classe de uso e ocupação do solo da bacia (classe agrícola, urbana e de cerrado). Esses valores foram obtidos por meio de amostragens realizadas na própria bacia e da literatura pertinente.

O valor do coeficiente de exportação de fósforo total da área agrícola foi encontrado de acordo com os seguintes passos:

- Obtenção do valor de fósforo total de uma área agrícola da bacia do ribeirão Pipiripau, por meio de amostragem realizada por SOUZA (2013, não publicado);

- Obtenção do valor da taxa de enriquecimento do fósforo solo/sedimento, dada por Pinheiro et al. (2010);

- Multiplicação do valor de fósforo total do solo de uma área agrícola da bacia do ribeirão pela taxa de enriquecimento do fósforo solo/sedimento;

- Obtenção da quantidade de solo da área agrícola da bacia, carreada para o corpo d'água, de acordo com o trabalho de Chaves (2012, não publicado);

- Cálculo do coeficiente de exportação de fósforo total para a classe agrícola, usando a seguinte equação:

$$
\operatorname{Coef}(\mathrm{Pt})=(\text { Lsolo } \cdot \mathrm{Lps}) / 100
$$

Onde Coef $(\mathrm{Pt})$ é o valor de coeficiente de exportação de fósforo total da área agrícola ( $\mathrm{Kg} / \mathrm{ha} / \mathrm{ano}) ;$ Lsolo é a carga de solo total carreada da área agrícola para o corpo d'água ( $\mathrm{Kg} / \mathrm{ha} / \mathrm{ano})$ e Lps é a porcentagem de fósforo total no sedimento.

Assim, os valores usados para o cálculo do coeficiente de exportação do fósforo total da classe agrícola, foram:

- Valor da concentração de fósforo total no solo de uma área agrícola da bacia: 25 ppm (Souza, 2013, não publicado);

- Valor da taxa de enriquecimento do fósforo solo/sedimento: 1,76 (Pinheiro et al., 2010); 
- Quantidade de solo da área agrícola da bacia, carreado para o corpo d'água: 10.000 $\mathrm{Kg}$ /ha/ano (Chaves 2012, não publicado).

O valor do coeficiente de exportação de fósforo total da área cerrado, por sua vez, foi encontrado de acordo com os seguintes passos:

- Obtenção do valor de fósforo total de uma área de cerrado da bacia do ribeirão Pipiripau, por meio de amostragem realizada por SOUZA (2013, não publicado);

- Obtenção do valor da taxa de enriquecimento do fósforo solo/sedimento, dada por Pinheiro et al. (2010);

- Multiplicação do valor de fósforo total do solo de uma área de cerrado da bacia do Pipiripau pela taxa de enriquecimento do fósforo solo/sedimento;

- Obtenção da quantidade de solo da área cerrado da bacia, carreado para o corpo d'água de acordo com o trabalho de Chaves (2010);

- Cálculo do coeficiente de exportação de fósforo total para a classe cerrado, usando a equação 4.2.

Os valores obtidos e usados para o cálculo do coeficiente de exportação do fósforo total da classe cerrado foram:

- Valor de fósforo total no solo de uma área de cerrado da bacia: 0,3 ppm (Souza, 2013, não publicado);

- Valor da taxa de enriquecimento do fósforo solo/sedimento: 1,76 (Pinheiro et al., 2010);

- Quantidade de solo da área cerrado da bacia, carreado para o corpo d'água: 1.000 $\mathrm{Kg} / \mathrm{ha} /$ ano (Chaves, 2010).

O coeficiente de exportação de fósforo total da área urbana foi obtido do trabalho de Salas e Martino (1991) (Tabela 4.5). Isso foi feito, porque não houve amostragem para esta área. É possível utilizar este valor de coeficiente de exportação de fósforo total para a área urbana, pois Salas e Martino (1991) relatam que os valores de coeficiente de exportação abordados em seu trabalho são de origem de bacias americanas, mas que foram confirmados com dados brasileiros.

Encontrados os valores de coeficientes de exportação para cada uso e ocupação do solo da 
bacia (Tabela 4.4), os mesmos foram multiplicados pelas áreas (ha) de cada classe de uso e ocupação do solo, de acordo com o agrupamento das classes.

Tabela 4. 4 - Valores de coeficientes de exportação de fósforo total para as três principais classes de uso e ocupação do solo da bacia do Pipiripau.

CLASSE DE USO E OCUPAÇÃO DO SOLO
COEFICIENTE DE EXPORTAÇÃO

DE FÓSFORO (Kg/ha/ano)
Urbana

Agrícola

Cerrado

Fonte: autoria própria (2013).
1,0

0,4

0,05

Tabela 4. 5 - Valores de coeficientes de exportação de fósforo total de acordo com o uso e ocupação do solo.

CLASSE DE USO E OCUPAÇÃO DO SOLO
COEFICIENTE DE EXPORTAÇÃO DE FÓSFORO (Kg/ha/ano)

\section{Urbana 1,2}

Agrícola $\quad 0,5$

\section{Cerrado \\ 0,1}

Fonte: Adaptado de Salas e Martino (1991).

Como procedimento final do cálculo da carga poluente de fósforo total na bacia (L), (Kg/ano), foi realizado o somatório dos valores provenientes da multiplicação dos coeficientes de exportação do fósforo total de cada classe de uso e ocupação do solo pela área de cada classe.

\subsubsection{Relação de aporte de sedimento (RAS) e fósforo total}

Utilizando-se o método exposto acima, calculou-se a carga de fósforo total que é carreada com o sedimento para o corpo d'água da bacia. Entretanto, há uma série de complexidades ligando o aporte de sedimento a jusante com a perda de solo a montante, e com o sedimento total erodido no interior da bacia, que chega ao seu exutório anualmente. 
Dessa forma, consideramos a suposição de Chaves et al (2004), que estabelece que a redução da erosão no interior da bacia implicará na mesma redução proporcional no aporte de sedimentos no seu exutório . Tal suposição encontra respaldo no trabalho de Renfro (1975).

A redução do aporte de sedimento no exutório da bacia, por sua vez, pode ser estimada pela relação de aporte de sedimento (RAS), largamente empregada em estudos sedimentológicos (RENFRO, 1975). Essa relação é dada pela seguinte equação:

$$
\mathrm{RAS}=\mathrm{Y} / \mathrm{E}
$$

Em que RAS $(0-1)$ = relação de aporte de sedimento; $\mathrm{Y}(\mathrm{t})$ = produção de sedimento no exutório da bacia; e $\mathrm{E}(\mathrm{t})$ erosão total na bacia.

De acordo com Chaves (2010), o aporte de sedimento médio na bacia do Pipiripau é atualmente de 1.550 t/ano, e a erosão total média, obtida do produto da perda de solo média pela área da bacia, no cenário climático atual, de $E=192.921$ t/ano. Assim, a relação de aporte de sedimento (RAS) para a bacia é de:

$$
\operatorname{RAS}(\%)=100(\mathrm{Y} / \mathrm{E})=100(1.550 / 192.921)=0,83 \%
$$

$\mathrm{O}$ valor de $\mathrm{RAS}=0,83 \%$ significa que, em média, pouco menos de $1 \%$ do sedimento total erodido no interior da bacia do rib. Pipiripau chega ao seu exutório anualmente, o que está de acordo com resultados de outras bacias semelhantes. (CHAVES, 2012, não publicado).

A perda de nutrientes (fósforo) pode ser expressa tanto em concentração do elemento em solução ou adsorvido no sedimento (SCHICK et al., 2000). Entretanto, Olivera (2007) constatou que na água da enxurrada não foram registradas perdas de fósforo total, devido aos baixos valores desse elemento no solo, pelo fato do mesmo estar adsorvido aos colóides do solo.

Segundo Oliveira (2007) o maior transporte de $\mathrm{P}$ se dá nas frações de argila e silte do sedimento. Assim, considerou-se que o carreamento de fósforo total para o corpo d'água ocorreu adsorvido no sedimento erodido. Dessa forma, foi utilizado o mesmo valor da relação de aporte de sedimento $(0,83 \%)$, no cálculo da carga (Lpe) de fósforo total que chega ao exutório da bacia. 


\subsubsection{Estimativa da concentração máxima de fósforo total no corpo d'água}

De acordo com CBH - PARANAÍBA (2012) e a partir da Resolução do Conselho Nacional do Meio Ambiente (CONAMA), n 357, de 17 de março de 2005, podemos concluir que :

- $\quad 85,8 \%$ dos dados de qualidade da água disponíveis na bacia enquadram o ribeirão Pipiripau nas classes $2(45,9 \%)$ e $3(39,9 \%)$, destinando suas águas ao abastecimento doméstico, após tratamento convencional e avançado, dentre outros usos;

- $10,8 \%$ dos resultados classificam o ribeirão Pipiripau na classe 4 , indicando o aproveitamento desse manancial para usos menos nobres, que não o abastecimento público. Os principais parâmetros que contribuíram para o decaimento da qualidade da água foram a cor, a turbidez e os coliformes fecais.

É importante mencionar que para efetivação dessa classificação apenas 7 parâmetros (cor, turbidez, $\mathrm{pH}$, cloreto, amônia, coliformes fecais e totais), que são rotineiramente monitorados pela Companhia de Saneamento Ambiental do Distrito Federal (CAESB) para a obtenção do IQA, foram avaliados.

Como a maior parte dos dados $(45,9 \%)$ classificam o Ribeirão Pipiripau como classe 2, consideramos essa informação para o cálculo da pegada hídrica cinza. Posto isso, segundo os padrões de qualidade estabelecidos pela Resolução CONAMA 357/2005 para águas doces de classe 2, a concentração máxima de fósforo total nos corpos d'água é de 0,050 $\mathrm{mg} / \mathrm{L}$.

\subsubsection{Estimativa da concentração natural de fósforo total no corpo d'água}

A concentração natural $\left(c_{\text {nat }}\right)$ em um corpo d'água receptor corresponde à concentração no corpo d'água que ocorreria se não houvesse intervenções humanas na bacia hidrográfica (HOEKSTRA et al., 2011). Segundo os autores, para substâncias de origem humana que naturalmente não ocorrem na água, $c_{\text {nat }}$ é igual a zero. Entretanto, de acordo com Liu et al. (2012), a concentração natural não pode ser igual a zero, pois mesmo sem ação antrópica, todos os rios naturalmente transportam alguns nutrientes.

Para o cálculo da concentração natural do fósforo total foi utilizada a seguinte equação: 


$$
\text { Cnat }=\text { Lnat } / Q
$$

Onde Cnat é a concentração natural da carga poluente no corpo d'água $(\mathrm{Kg} / \mathrm{L})$; Lnat a carga de poluente $(\mathrm{Kg} / \mathrm{L})$ e Q é a vazão da bacia $\left(\mathrm{m}^{3} / \mathrm{s}\right)$.

Nessas condições, o valor de Lnat foi baseado nos valores da classe cerrado, a qual representa as condições naturais da bacia, ou seja, sem interferência humana. Assim sendo, a carga L, nessas condições, foi encontrada multiplicando-se o valor do coeficiente de exportação da classe cerrado pela área da bacia (sem considerar a área dos corpos d'água).

Por fim, o valor da carga Lnat encontrada foi multiplicado pelo valor de RAS para estimar a carga de fósforo total, nas condições naturais (originais) da bacia.

Os dados hidrológicos de vazões utilizados foram obtidos no portal HIDROWEB da ANA para a estação FRINOCAP (código 60473000), para o ano de 2010. Para essa seção, o valor médio das vazões médias mensais do ano de 2010 foi de $1,77 \mathrm{~m}^{3} / \mathrm{s}$.

\subsubsection{Cálculo da pegada hídrica usando o valor da concentração de fósforo total medida}

Com o propósito de comparar a pegada hídrica cinza obtida por meio do uso de coeficientes de exportação de fósforo total com a pegada hídrica cinza obtida através do valor da concentração de fósforo total medida no ribeirão estudado, o seguinte processo foi feito:

- Obtenção da concentração de fósforo total no ribeirão Pipiripau. Tal dado foi obtido de PGIRH - DF (2006), sendo essa a concentração média anual do fósforo total, obtida entre nos anos entre 1991 e 2009;

- Cálculo da carga de fósforo total (Kg/ano) usando o valor da concentração de fósforo total no ribeirão (Equação 4.5);

- Cálculo da pegada hídrica cinza (Equação 4.1):

$$
\mathrm{L}(\mathrm{Pt})=\mathrm{C} \cdot \mathrm{V}
$$

Onde L (Pt) é a carga de fósforo total (Kg/ano); C é a concentração de fósforo total ( $\mathrm{mg} / \mathrm{L})$ e $\mathrm{V}$ a vazão média do rio $\left(\mathrm{m}^{3} / \mathrm{s}\right)$. 
Os valores obtidos e usados para o cálculo da carga de fósforo total e da pegada hídrica cinza, foram:

- Valor médio da concentração de fósforo total no ribeirão Pipiripau: $0,02 \mathrm{mg} / \mathrm{L}$ (PGIRH - DF, 2006);

- Valor da vazão média anual de 2010: $1,77 \mathrm{~m}^{3} / \mathrm{s}$ (ANA, 2010).

\subsubsection{Cálculo da pegada hídrica cinza em diferentes condições de uso e ocupação do solo}

Foi realizado o cálculo da pegada hídrica cinza para diferentes cenários de uso e ocupação do solo. Foram eles:

- Condição 1: Uso e ocupação da bacia hidrográfica do ribeirão Pipiripau 100\% Agrícola;

- Condição 2: Uso e ocupação da bacia hidrográfica do ribeirão Pipiripau 100\% Urbano;

- Condição 3: Uso e ocupação da bacia hidrográfica do ribeirão Pipiripau $100 \%$ cerrado;

- Condição 4: Uso e ocupação da bacia hidrográfica do ribeirão Pipiripau $50 \%$ Agrícola e 50\% Urbano.

Para o cálculo das pegadas hídricas cinza das condições 1,2 e 3, a área considerada foi de 23.495,7 ha, que é a área de solo total da bacia. Para a condição 4, a área considerada foi $11.747,8$ ha para a classe agrícola e $11.747,8$ ha, para a classe urbano.

A metodologia usada para calcular a pegada hídrica cinza da bacia nas condições atuais de uso e ocupação do solo foi a mesma usada para o cálculo da pegada hídrica cinza nas quatro condições de uso e ocupação do solo.

\subsubsection{Avaliação da sustentabilidade da pegada hídrica cinza}

Para avaliar a sustentabilidade da pegada hídrica cinza, dois passos foram considerados:

1. Identificar e quantificar o critério de sustentabilidade;

2. Identificar os pontos críticos dentro da bacia. 
Passo 1: Identificação e quantificação do critério de sustentabilidade:

A sustentabilidade da pegada hídrica dentro de uma bacia pode ser analisada sob três perspectivas diferentes: ambiental, social e econômica. Para cada uma das perspectivas existem alguns critérios de sustentabilidade. Um dos critérios de sustentabilidade explicita quando uma pegada hídrica em uma bacia hidrográfica já não pode ser considerada sustentável.

Neste trabalho, foi avaliada a sustentabilidade ambiental da pegada hídrica cinza, uma vez que consideramos apenas as questões de qualidade de água e não o fornecimento de água (critério social) ou a eficiência em seu uso ou alocação (critério econômico).

Para considerar a pegada hídrica cinza sustentável ambientalmente, a qualidade da água deve permanecer dentro de certos limites, ou seja, seguindo os padrões de qualidade da água em seu estado natural. Os padrões de qualidade da água aqui seguidos são os apresentados pela resolução CONAMA 357/2005, para a classe na qual a bacia se insere.

Passo 2: Identificação dos pontos críticos dentro da bacia:

Os pontos críticos são os locais e os períodos do ano em que as pegadas hídricas não são sustentáveis e precisam ser reduzidas (HOEKSTRA et al., 2011). Os períodos do ano em que a pegada hídrica cinza é insustentável não foram considerados como um ponto crítico, pois o valor de pegada hídrica encontrado não se refere a um período específico do ano (período da seca, por exemplo), mas ao período de um ano como um todo.

A respeito do ponto crítico da pegada hídrica cinza, considerou, neste trabalho, o exutório da bacia, pois a carga de fósforo total quantificada que ali chega é proveniente de todos os usos e ocupações do solo da bacia, exportadores de fósforo ${ }_{2}$ a montante.

Para identificar se o exutório da bacia hidrográfica do ribeirão Pipiripau é um ponto crítico, tomou-se como critério de sustentabilidade ambiental a capacidade de assimilação do fósforo. No caso da pegada hídrica cinza, a capacidade de assimilação residual foi obtida calculando-se o nível de poluição da água (WPL) dentro da bacia. Tal nível é definido como a fração consumida da capacidade de assimilação de resíduos, e calculado pela razão entre o total das pegadas hídricas cinza $\left(\Sigma \mathrm{PH}_{\text {cinza }}\right)$ e o escoamento real da bacia $\left(\mathrm{R}_{\mathrm{act}}\right)$. Um nível de poluição de água de 100\% significa que a capacidade de assimilação de resíduos foi totalmente utilizada. Quando o nível de poluição excede $100 \%$, os padrões de qualidade 
da água em seu estado natural são desrespeitados. O nível de poluição da água é calculado para uma bacia $\mathrm{x}$ e tempo $\mathrm{t}$, da seguinte forma:

$$
W P L[x, t]=\frac{\sum W F_{\text {grey }}[x, t]}{R_{a c t}[x, t]}
$$

\subsubsection{Formulação da resposta da pegada hídrica}

A formulação da resposta da pegada hídrica consiste em um inventário de ações que podem ser consideradas para a redução da pegada hídrica. Várias opções de resposta existem e dependem da avaliação e resultados dos processos anteriores. Neste trabalho, a formulação da resposta à pegada hídrica cinza depende dos resultados da contabilização e avaliação da sustentabilidade da pegada hídrica cinza. Caso a contabilização da pegada hídrica cinza apresente valores altos, ou seja, a pegada hídrica cinza tenha valor próximo ou maior do que o fluxo do rio, desrespeitando os padrões de qualidade da água em seu estado natural, e consequentemente apresentando-se insustentável ambientalmente, a formulação da resposta à pegada hídrica deverá abranger ações de controle e redução da pegada bem como os responsáveis por essas ações. Em contrapartida, se a pegada hídrica cinza apresentar valores que não desrespeitem os padrões de qualidade de água, ou seja, sustentável ambientalmente, as ações propostas devem ser, principalmente, para manutenção desta pegada hídrica ou até mesmo atingir o status de "água neutro", que ocorre quando se obtém a redução da pegada hídrica de uma atividade tanto quanto possível.

\section{RESULTADOS E DISCUSSÃO}

\subsection{CARGA DE FÓSFORO TOTAL NA BACIA}

$\mathrm{Na}$ tabela seguinte, são expostos os valores dos coeficientes de exportação das áreas de uso e ocupação do solo da bacia, bem como o resultado do somatório dos valores provenientes da multiplicação dos coeficientes de exportação do fósforo total das áreas de uso e ocupação do solo pela área de cada classe. 
Tabela 5.1 - Multiplicação da área da classe de cada uso e cupação do solo pelo coeficiente de exportação de cada classe.

\begin{tabular}{|c|c|c|c|}
\hline $\begin{array}{c}\text { CLASSE DE } \\
\text { CADA USO } \\
\text { E } \\
\text { OCUPAÇÃO } \\
\text { DO SOLO }\end{array}$ & $\begin{array}{c}\text { ÁREA } \\
\text { (ha) }\end{array}$ & $\begin{array}{c}\text { COEFICIENTE DE } \\
\text { EXPORTAÇÃO DE } \\
\text { FÓSFORO } \\
\text { (Kg/ha/ano) }\end{array}$ & $\begin{array}{c}\text { ÁREA DA CLASSE DO } \\
\text { USO E OCUPAÇÃO DO } \\
\text { SOLO X COEFICIENTE } \\
\text { DE EXPORTAÇÃO DE } \\
\text { FÓSFORO (kg/ano) }\end{array}$ \\
\hline Urbana & $1.181,9$ & 1,0 & $1.181,9$ \\
\hline Agrícola & $16.306,4$ & 0,4 & $6.522,6$ \\
\hline Cerrado & $6.007,3$ & 0,05 & 300,4 \\
\hline
\end{tabular}

Fonte: autoria própria (2013).

\subsection{CÁLCULO DA CARGA DE FÓSFORO TOTAL NO EXUTÓRIO DA BACIA}

O valor $8.004,9 \mathrm{Kg} / \mathrm{ano}$, indicado na Tabela 5.1, é referente à carga total de Pt que deixa as áreas de onde ele é proveniente, e não o que chega ao exutório da bacia.

Considerando que o fósforo total $(\mathrm{Pt})$ carreado para o corpo d'água é dominantemente transportado através do sedimento erodido, o valor da carga de fósforo total (Lpe) que chega ao exutório da bacia foi:

$$
\text { Lpe }=8.004,9 * 0,0083=66,4 \mathrm{~kg} / \mathrm{ano}
$$

Assim, o valor esperado da carga de fósforo total que chega ao exutório da bacia é de 66,4 Kg/ano.

\subsection{ESTIMATIVA DA CONCENTRAÇÃO NATURAL DE FÓSFORO TOTAL DO CORPO D'ÁGUA}

O valor da carga natural de Pt obtido (1.174,8 kg/ano), depois de multiplicado pelo valor de RAS da bacia $(0,0083)$, resultou em um valor de carga natural de fósforo total de 9,7 $\mathrm{kg} / \mathrm{ano}$.

Além disso, aplicando a equação 4.4 juntamente com o valor da carga natural que chega ao exutório $(9,7 \mathrm{Kg} / \mathrm{ano})$, e o valor da vazão média de $1,77 \mathrm{~m}^{3} / \mathrm{s}$, bem como fazendo as transformações de unidade necessárias, foi obtido um valor de concentração natural de fósforo total de $1,7 \times 10^{-10} \mathrm{Kg} / \mathrm{L}$. 


\subsection{CONTABILIZAÇÃO DA PEGADA HÍDRICA CINZA (P)}

O valor da pegada hídrica cinza nas condições atuais de uso e ocupação do solo da bacia, foi de $0,04 \mathrm{~m}^{3} / \mathrm{s}$. Apesar de o valor da pegada hídrica cinza ter sido maior que zero, isso não significa, automaticamente, que os padrões de qualidade da água do ribeirão Pipiripau em seu estado natural foram desrespeitados. De acordo com Hoekstra et al. (2011), isso mostra apenas que fração da capacidade de assimilação de fósforo total do curso d'água já foi utilizada.

Enquanto a pegada hídrica cinza for menor do que a vazão média do rio, ainda há água suficiente para diluir os poluentes, mantendo a concentração abaixo do padrão mínimo desejável. Considerando a vazão média de $1,77 \mathrm{~m}^{3} / \mathrm{s}$, e que a vazão mínima é superior à PHcinza, a diluição do fósforo total ocorre sem maiores problemas na bacia estudada, utilizando esta apenas $2,2 \%$ da vazão média do ribeirão estudado.

\subsection{CÁlCULO DA PEGADA HÍDRICA USANDO O VALOR DA CONCENTRAÇÃO DE FÓSFORO TOTAL MEDIDO NA ÁGUA}

Segundo PGIRH - DF (2006), o valor médio da concentração do fósforo total na água no rib. Pipiripau, para o período entre 1991 e 2009, foi de $0,02 \mathrm{mg} / \mathrm{L}$.

Após as transformações de unidades necessárias, a carga de fósforo total encontrada para o ribeirão Pipiripau, utilizando os dados observados na bacia, foi de 111,6 Kg/ano.

Assim, o valor da pegada hídrica cinza, usando os dados locais foi de $0,07 \mathrm{~m}^{3} / \mathrm{s}$, ou seja, 75\% maior em comparação ao resultado com o cálculo usando coeficientes de exportação da literatura (Figura 5.1). Isso se deu pelo fato de que o valor médio da concentração média medida ter sido maior que a concentração obtida por meio do coeficiente de exportação.

Apesar dos resultados não apresentarem riscos à qualidade da água do ribeirão Pipiripau, tendo em vista que a assimilação de fósforo total na água nesses valores ocorre normalmente, questões relativas às duas formas com que o valor de pegada hídrica cinza foi calculado, devem ser avaliadas. 


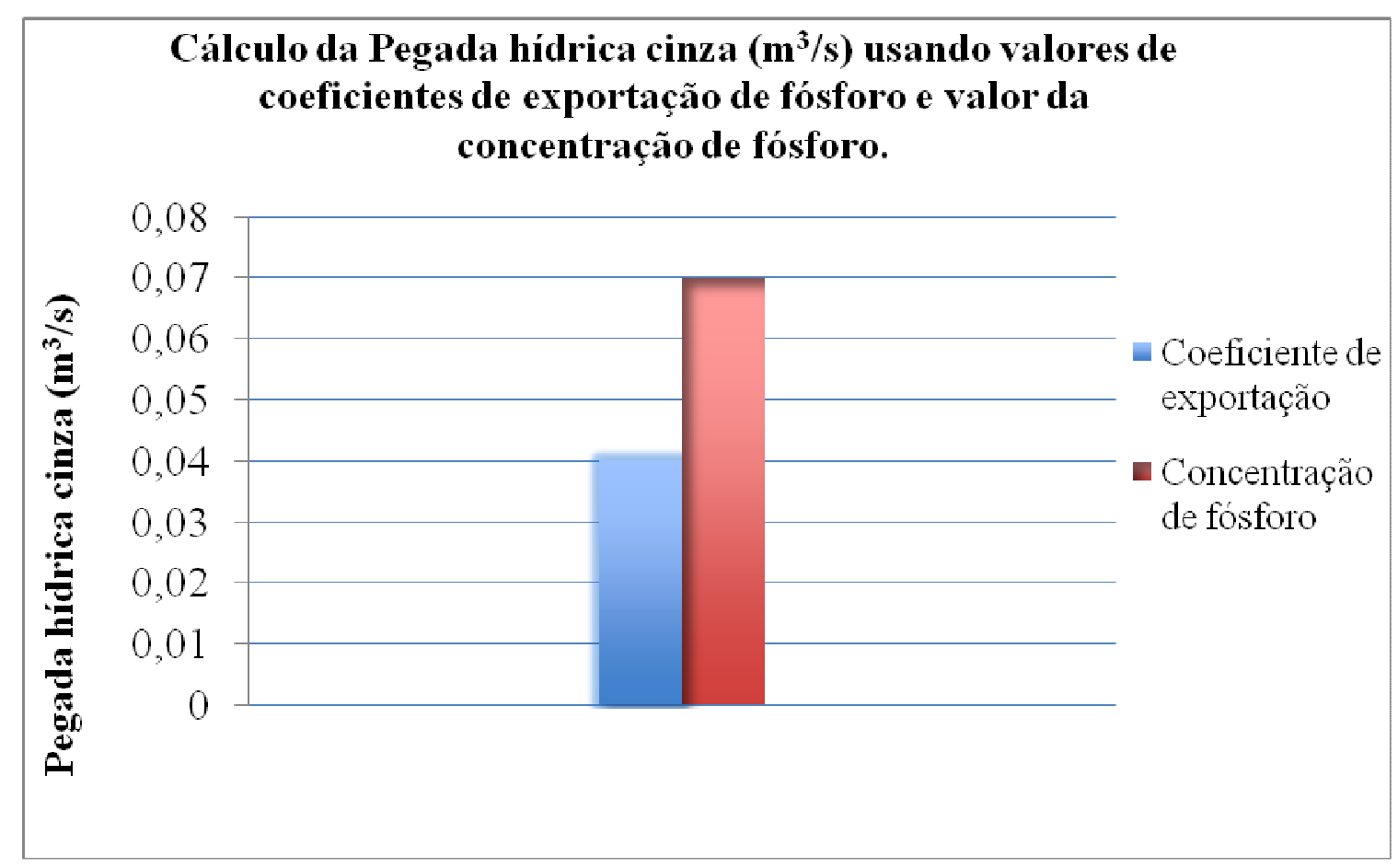

Figura 5. 1 - Comparação da pegada hídrica cinza no ribeirão Pipiripau calculada com o uso de coeficientes de exportação e com o valor da concentração de fósforo total na água. Fonte: autoria própria (2013).

Assim como no cálculo da pegada hídrica cinza, por meio do uso de coeficientes de exportação, a concentração de fósforo total medida no ribeirão Pipiripau (PGIRH - DF, 2006), refere-se às médias anuais de concentração de fósforo total no corpo d'água. Entretanto, os valores médios não são bons indicadores da concentração de $\mathrm{P}$, uma vez que a mesma pode aumentar significativamente após eventos chuvosos, durante o período de preparo do solo (SORRENSON; MONTOYA, 1984).

Nesse sentido, o uso do valor médio medido da concentração de fósforo total no cálculo da pegada hídrica cinza pode ter subestimado o valor dessa última, mesmo porque picos de hidrogramas e sedimentogramas ocorrem poucas vezes no ano, e durante poucas horas.

\subsection{CÁlCULO DA PEGADA HÍDRICA CINZA EM DIFERENTES CONDIÇÕES DE USO E OCUPAÇÃO DO SOLO}

\subsubsection{Pegada Hídrica no Cenário 1}

Para o Cenário 1 (100\% de agricultura na bacia), a pegada hídrica foi de $0,05 \mathrm{~m}^{3} / \mathrm{s}$, ou seja um aumento de $25 \%$ em relação à pegada hídrica atual. 


\subsubsection{Pegada Hídrica no Cenário 2}

No Cenário 2 (100\% de área urbana), a pegada hídrica da bacia do rib. Pipiripau seria de $0,12 \mathrm{~m}^{3 /} \mathrm{s}$, ou seja um aumento de $200 \%$ em relação à pegada hídrica atual

\subsubsection{Pegada Hídrica no Cenário 3}

Sob o Cenário 3 (100\% cerrado original), a pegada hídrica seria de apenas $0,006 \mathrm{~m}^{3} / \mathrm{s}$, havendo uma redução de 85\% em relação à pegada hídrica sob a condição atual.

\subsubsection{Pegada Hídrica no Cenário 4}

No caso do Cenário 4 (50\% agricultura e 50\% urbano), a pegada hídrica da bacia seria de $0,09 \mathrm{~m}^{3} / \mathrm{s}$, ou seja, um aumento de $125 \%$ em relação à pegada hídrica na situação atual.

A Figura 5.2 apresenta o resumo das pegadas hídricas nos distintos cenários analisados. Os resultados indicam que a maior pegada hídrica se daria no cenário $100 \%$ urbano, seguido do cenário $50 \%$ agrícola e $50 \%$ urbano, e que no cenário $100 \%$ cerrado haveria uma significativa redução da pegada hídrica da bacia, em relação à condição atual.

Esses resultados condizem com aqueles reportados por Von Sperling (2005), onde a ocupação do solo por matas e floresta, agricultura e ocupação urbana representam, usualmente, uma etapa inferior, intermediária e superior no processo de deterioração de um corpo d'água, respectivamente. 


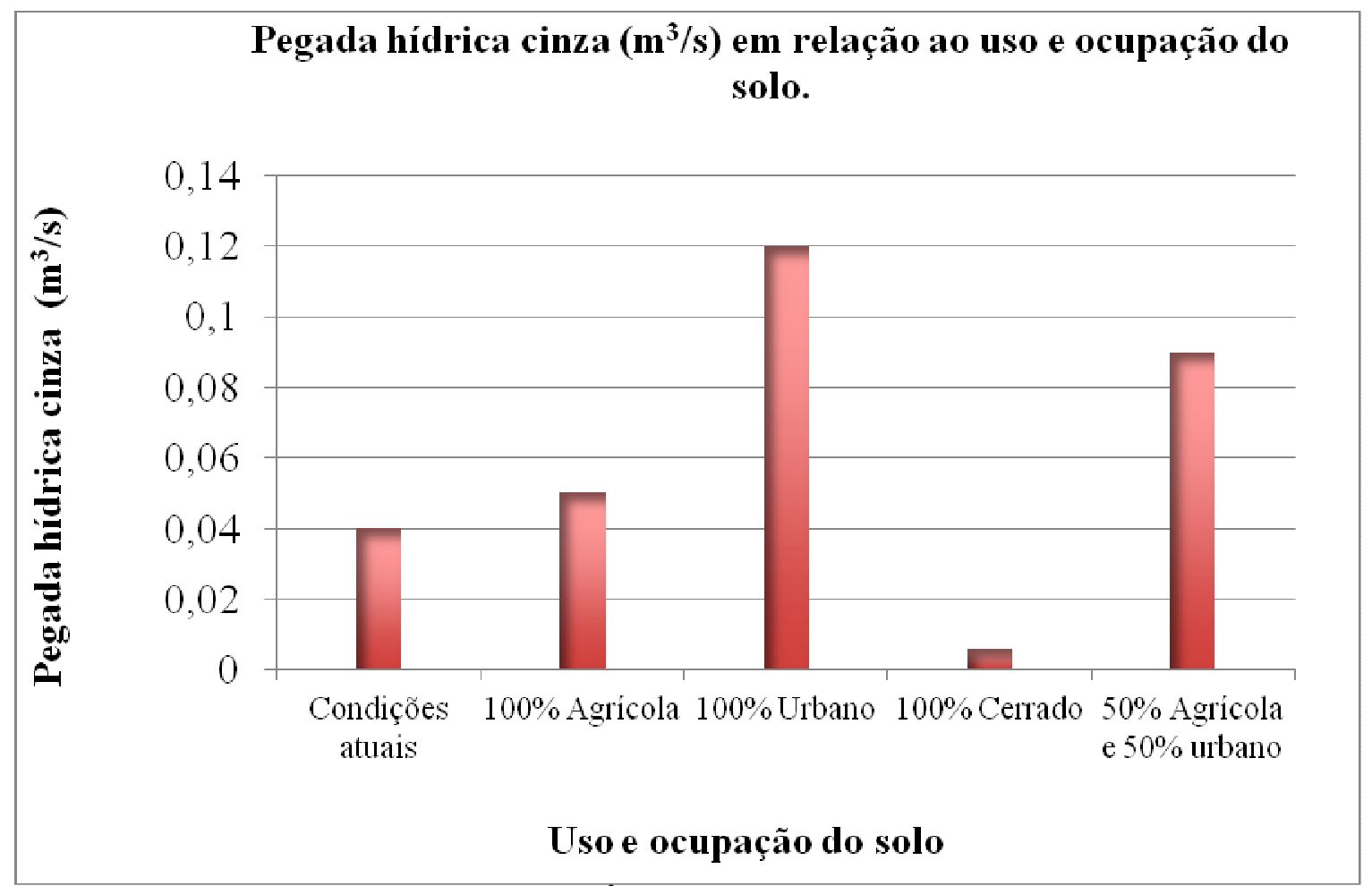

Figura 5. 2 - Pegada hídrica cinza de fósforo $\left(\mathrm{m}^{3} / \mathrm{s}\right)$ no ribeirão Pipiripau, usando coeficientes de exportação. Fonte: autoria própria (2013).

CALVIN (2008), também demonstra a maior contribuição de exportação de nutrientes por áreas urbanas. Em seu trabalho, este autor fez a relação entre o aumento da cobertura do solo para superficies impermeáveis e o aumento do escoamento de água. Ele descreve que bacias hidrográficas com coberturas impermeáveis entre $10 \%$ e $20 \%$ produzem um aumento de 2 vezes no escoamento, 35\% e 50\% de coberturas impermeáveis aumentam o escoamento em 3 vezes, e $75 \%$ e 100\% aumentam o escoamento em 5 vezes em relação as áreas florestadas, levando a um comprometimento da qualidade do ecossistema aquático.

Zaffani et al. (2011) calculou a pegada hídrica cinza para fósforo total em três pontos de monitoramento na sub-bacia do Monjolinho (São Carlos - SP) com diferentes áreas de drenagem e índice de urbanização para cada ponto. Os resultados demonstraram valor de pegada hídrica cinza para fósforo total maior que a vazão do rio nos três pontos. Entretanto, o ponto de alta urbanização foi o que apresentou a maior pegada hídrica.

Xavier (2005) relata a influência das atividades antrópicas sobre a qualidade da água. Este autor declara, corroborando com este trabalho, que a perda de fósforo pela enxurrada aumenta à medida que as florestas diminuem e as áreas com agricultura aumentam.

Estudos realizados em bacias hidrográficas dos Estados Unidos apresentam a seguinte 
relação em termos de quantidade de fósforo solúvel na enxurrada e tipo de uso do solo (XAVIER, 2005):

- Áreas com $90 \%$ de florestas - 0,009 $\mathrm{mg} \mathrm{L}^{-1}$ fósforo solúvel;

- Áreas com $75 \%$ de florestas - 0,012 $\mathrm{mg} \mathrm{L}-^{1}$ fósforo solúvel;

- Áreas com $50 \%$ de florestas $-0,014 \mathrm{mg} \mathrm{L}^{-1}$ fósforo solúvel;

- Áreas com $50 \%$ de florestas e $50 \%$ de agricultura $-0,025 \mathrm{mg} \mathrm{L}^{-1}$ fósforo solúvel;

- Áreas com $50 \%$ de agricultura - 0,037 $\mathrm{mg} \mathrm{L}^{-1}$ fósforo solúvel;

- Áreas com $90 \%$ de agricultura - 0,071 $\mathrm{mg} \mathrm{L}^{-1}$ fósforo solúvel.

\subsection{AVALIAÇÃO DA SUSTENTABILIDADE DA PEGADA HÍDRICA CINZA}

\subsubsection{Cenário atual}

A sustentabilidade da PHcinza para as condições atuais do uso e ocupação do solo na bacia do ribeirão Pipiripau foi de $2,2 \%$, ou seja, em média, somente $2,2 \%$ da capacidade de assimilação de fósforo total da água é utilizada.

\subsubsection{Cenário 1 (100\% de agricultura na bacia)}

A sustentabilidade da PHcinza para o cenário de 100\% agrícola na bacia foi de 2,8\%, ou seja, em média, somente $2,8 \%$ da capacidade de assimilação de fósforo total seria utilizada.

\subsubsection{Cenário 2 (100\% de área urbana)}

A sustentabilidade da PHcinza para tal cenário na bacia foi de 6,78\%, ou seja, em média, somente $6,78 \%$ da capacidade de assimilação de fósforo total seria utilizada.

\subsubsection{Cenário 3 (100\% cerrado original)}

Nesse cenário, a sustentabilidade da PHcinza foi de $0,3 \%$, ou seja, em média, somente $0,3 \%$ da capacidade de assimilação de fósforo total seria utilizada. 


\subsubsection{Cenário 4 (50\% agricultura e $50 \%$ urbano)}

A sustentabilidade da PHcinza para o cenário de 50\% de área agrícola e 50\% de área urbana na bacia foi de 5,1\%, ou seja, em média, somente $5,1 \%$ da capacidade de assimilação de fósforo total seria utilizada.

A Figura 5.3 apresenta o resumo da sustentabilidade da pegada hídrica cinza (P) para os diferentes cenários de uso e ocupação do solo na bacia do ribeirão. Pipiripau.

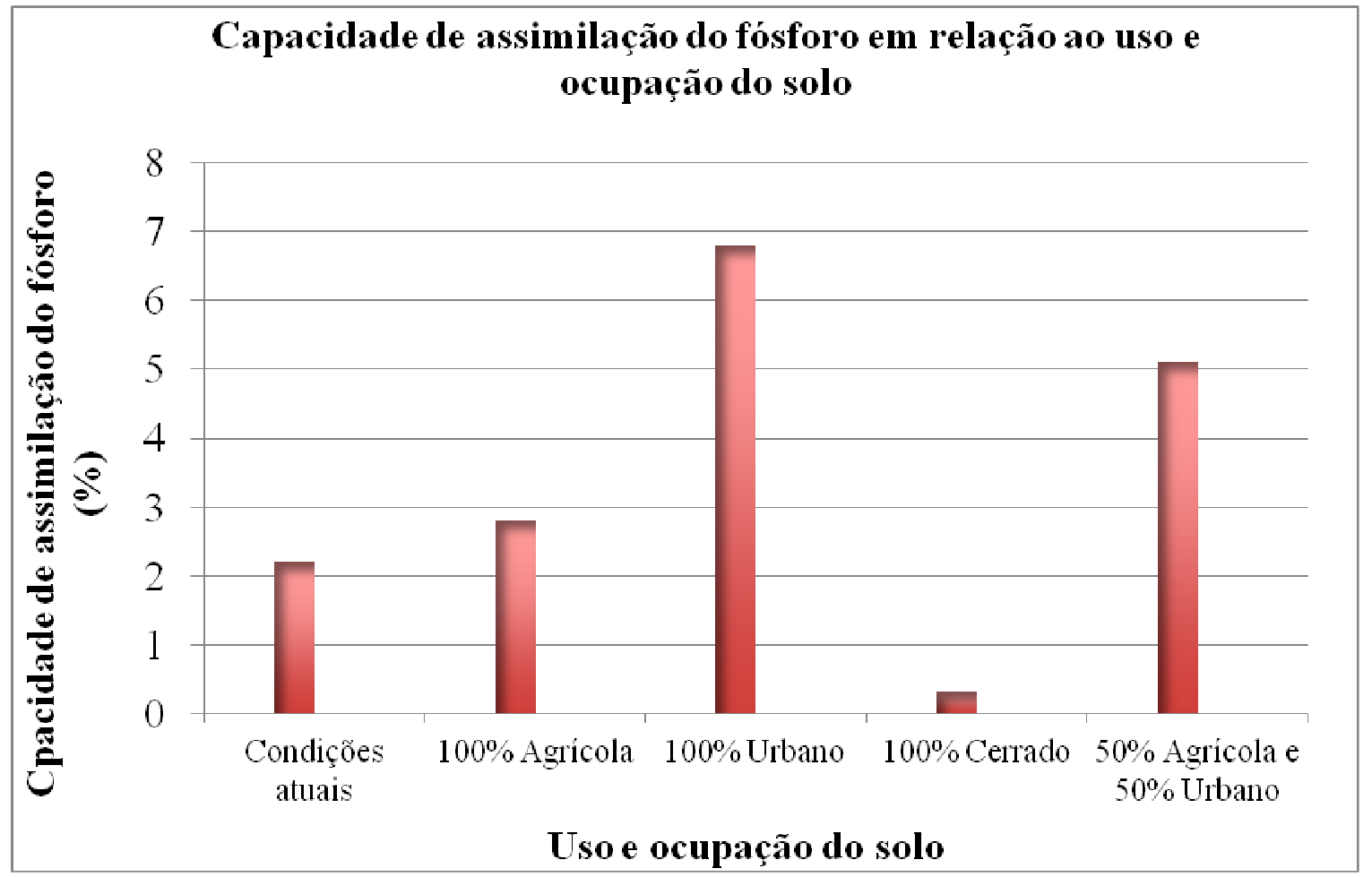

Figura 5.3 - Capacidade de assimilação do fósforo em relação aos diferentes usos e ocupação do solo na bacia do ribeirão Pipiripau. Fonte: autoria própria (2013).

De acordo com a Figura acima, observa-se que em todos os cenários analisados, a sustentabilidade ambiental da pegada hídrica do fósforo total é ainda elevada, ou seja, menos de $10 \%$ da capacidade de assimilação de $\mathrm{P}$ do ribeirão seria utilizada se eles viessem a ocorrer.

Entretanto, considerando que outras pegadas hídricas cinzas podem ocorrer concomitantemente com a do $\mathrm{P}(\mathrm{N}, \mathrm{Al}, \mathrm{Me}, \mathrm{Cu}$, etc..), se faz necessário a avaliação da pegada hídrica cinza de cada possível poluente isoladamente para identificar se o fósforo total, aqui analisado, é o poluente mais crítico. 
Entende-se como poluente mais crítico aquele que gera o maior volume de água para sua assimilação. Essa questão se respalda em Hoekstra et al. (2011), quando esses exemplificam o procedimento da contabilização da pegada hídrica cinza do crescimento de uma plantação ou floresta. Os autores relatam, de forma clara, que é necessário contabilizar somente o elemento poluente mais crítico, que é o poluente que gera o maior volume de água, após o cálculo da sua pegada hídrica cinza.

A utilização do poluente mais crítico para avaliar a sustentabilidade ambiental da bacia hidrográfica parte do pressuposto que a quantidade de água necessária para assimilar tal poluente é suficiente para assimilar outros poluentes que possam ocorrer, uma vez que o volume de água necessário para isso é menor em relação ao volume necessário para assimilação do poluente crítico. Apesar de várias pegadas hídricas cinza de diversos poluentes ocorrerem concomitantemente, não é possível a somatória dessas pegadas, uma vez que a água usada na contabilização das pegadas hídricas e que assimila estes poluentes é a mesma. Assim, a contabilização e a avaliação da sustentabilidade da pegada hídrica cinza de uma bacia hidrográfica deve ser de acordo com o poluente mais crítico presente.

O aumento da carga de poluentes carreados para os corpos hídricos, além do fósforo, devido às mudanças do uso e ocupação do solo, podendo um deles se tornar o poluente mais crítico, pode ser corroborado com o trabalho de CALVIN (2008). Esse autor demonstra que mudanças no uso e ocupação do solo de bacias hidrográficas (neste caso, o aumento da porcentagem de urbanização) apresenta relação direta com o aumento do carregamento não só de fósforo, mas de outros poluentes, como nitrato e amônia a jusante.

Ainda em relação às cargas críticas, Hoekstra e Mekonnen (2011), após estudarem a pegada hídrica cinza, no tocante ao nitrogênio aplicado como fertilizante de vários tipos de culturas e derivados de produtos agrícolas, encontraram como resultado um valor baixo, ou seja, bem menor que o padrões de qualidade de água aceitáveis. Entretanto, os autores chegaram à conclusão que isso ocorreu porque eles analisaram o volume necessário de água apenas para a assimilação de nitrogênio lixiviado, deixando de fora outros poluentes relevantes, tais como fósforo e pesticidas. 


\subsection{FORMULAÇÃO DE RESPOSTAS DA PEGADA HÍDRICA CINZA}

Supondo que seja realizada a contabilização das pegadas hídricas cinza de outros poluentes que ocorrem concomitantemente com a pegada hídrica cinza do fósforo total, e verificada a insustentabilidade ambiental por parte de alguma das pegadas hídricas, medidas de controle e redução podem ser tomadas como forma de resposta à pegada hídrica cinza, entre elas:

- Estimativa do crescimento populacional, das atividades industriais e agrícolas da bacia;

- Adoção de incentivos econômicos aos prestadores de serviços ambientais;

- Implantação ou melhoria da coleta e destinação do lixo;

- Ações que visam o manejo adequado do solo para controle da erosão;

- Implementação de sistema de drenagem de águas pluviais;

- Manejo adequado de agrotóxicos e fertilizantes;

- Recuperação de área degradadas;

- Implantação/melhoria da rede de monitoramento da qualidade da água;

- Recomposição das matas ciliares e de nascentes;

- Conscientização da sociedade.

Essas medidas dependem de vários atores, entre eles órgãos gestores de recursos hídricos e de meio ambiente, governantes, comitês de bacia, empresas de saneamento, indústrias, agricultores, universidade, entre outros.

\section{CONCLUSÕES E RECOMENDAÇÕES}

Tomando como base os dados encontrados, concluiu-se que:

- A carga difusa de fósforo total transportada para o exutório da bacia do ribeirão Pipiripau foi de 66,4 Kg/ano.

- O uso do coeficiente de exportação para encontrar a carga de fósforo total que chega ao exutório da bacia demonstrou ser prático e simples. Recomendam-se às pesquisas posteriores estudos de campo, de forma a validar os valores dos coeficientes de exportação; 
- A pegada hídrica cinza do fósforo total obtida para as condições atuais de uso e ocupação do solo da bacia hidrográfica do ribeirão Pipiripau foi de $0,04 \mathrm{~m}^{3} / \mathrm{s}$. Este resultado indica que esse corpo hídrico apresenta condições suficientes para a diluição de $\mathrm{P}$, ou seja, a capacidade de assimilação da carga de fósforo total foi utilizada minimamente;

- A pegada hídrica cinza atual da bacia hidrográfica do ribeirão Pipiripau, nas condições atuais de uso e ocupação do solo é sustentável ambientalmente, estando dentro dos limites dos padrões de qualidade da água em seu estado natural;

- O exutório da bacia hidrográfica do ribeirão Pipiripau não representa um ponto crítico, pois seu nível de poluição (WPL) não excede $100 \%$ e os padrões de qualidade da água em seu estado natural não são desrespeitados;

- O valor da pegada hídrica cinza, calculado por meio dos coeficientes de exportação de fósforo total foi menor do que o valor da pegada hídrica encontrado através da concentração de fósforo total na água;

- O uso de uma única medida mensal da concentração de fósforo total na água pode gerar valores superestimados ou subestimados ao cálculo. Recomenda-se monitorar diariamente a concentração de fósforo total na água para realizar o cálculo da pegada hídrica cinza;

- O cenário de uso e ocupação do solo que apresentou maior valor de pegada hídrica cinza de $\mathrm{P}$ foi a classe $100 \%$ urbana, seguida pela classe $50 \%$ agrícola e $50 \%$ urbana, e a classe $100 \%$ agrícola, demonstrando uma maior contribuição para o carreamento da carga de fósforo total em relação aos usos atuais e pretéritos (cerrado);

- As pegadas hídricas cinza para a condição atual e para os diferentes cenários de uso e ocupação do solo mostraram-se sustentáveis ambientalmente, estando dentro dos limites dos padrões de qualidade da água em seu estado natural; 
- Recomenda-se a avaliação da pegada hídrica cinza de outros possíveis poluentes que são carreados ao ribeirão Pipiripau, para identificar se o fósforo total é o poluente mais crítico e consequentemente analisar a sustentabilidade ambiental da pegada hídrica da bacia e propor medidas mitigadoras para redução da pegada hídrica cinza na bacia.

\section{REFERÊNCIAS BIBLIOGRÁFICAS}

ARAÚJO, L.E. et al. Bacias hidrográficas e impactos ambientais. Qualit@s, Paraíba, v. 8, n.1, p. $1-18,2009$.

BASNYAT, P. et al. The use of remote sensing and GIS in the watershed level analyses of non-point source pollution problems. Forest Ecology and Management. Alburn. 2000, v. 128, p. 65-73.

BOSSCHE, H.V. et al. Phosphorus losses from sewage sludge disposed on a field: evidence from storm event simulations. Water Science and Technology. Oxford. 2000, v. 42, n. 9, p.179-186.

BRASIL. Agência Nacional de Águas, ANA; The Nature Conservancy, TNC; Empresa de Assistência Técnica e Extensão Rural do Distrito Federal, EMATER; Secretaria de Agricultura Pecuária e Abastecimento, SEAPA. Programa Produtor de Água: Relatório de diagnóstico socioambiental da bacia do ribeirão Pipiripau. 59 p. 2010 .

BRASIL. Conselho Nacional do Meio Ambiente - CONAMA Resolução 357/2005, Publicada no DOU n 53, de 18 de março de 2005, Seção 1, páginas 58-63 Enquadramento dos Corpos Hídricos Superficiais no Brasil.. Governo Federal, Brasilia.

CAESB. Relatório Sobre o Plano de Proteção Ambiental da Bacia Hidrográfica do Ribeirão Pipiripau. Brasília, 2001.

CALVIN, A.B. Relationship between Land Use and Surface Water Quality in a Rapidly Developing Watershed in Southeast Louisiana. 2008. $171 \mathrm{f}$. Tese (Doutorado em engenharia e ciência aplicada) - Universidade de New Orleans, New Orleans, 2008.

CAMPOS, Y. O. Gestão ambiental: complexidade sistêmica em bacia hidrográfica. 2010. 186 f. Tese (Doutorado em Geografia e Gestão do Território) - Universidade Federal de Uberlândia, Uberlândia, 2010.

CHAPAGAIN, A.K., et al. The water footprint of cotton consumption: an assessment of the impact of worldwide consumption of cotton products on the water resources in the cotton producing countries. Ecological economics. Netherlands, 2006, n. 60, p. $186-203$.

CHAPAGAIN, A.K. e HOEKSTRA, A.Y. The blue, green and grey water footprint of rice 
from production and consumption perspectives. Ecological economics. Netherlands, 2011, n. 70, p. $749-758$.

CHAVES, H. M. L. e PIAU, L.P. Efeito da variabilidade da precipitação pluvial e do uso e manejo do solo sobre o escoamento superficial e o aporte de sedimento de uma bacia hidrográfica do distrito federal. R. Brasileira Ciência do Solo, Campinas, n. 32, p. 333-343, 2008.

CHAVES, H.M.L. Relações de aporte de sedimento e implicações de sua utilização no pagamento por serviço ambiental em bacias hidrográficas. R. Brasileira Ciência do Solo, Campinas, n. 34, p. 1469-1477, 2010.

CHAVES, H.M.L. Relatório de Avaliação econômica e socioambiental do retorno do investimento da implantação do projeto produtor de água na bacia do ribeirão Pipiripau (DF/GO), 2012. Trabalho não publicado.

CHAVES, H.M.L. et al. Quantificação dos benefícios ambientais e compensações financeiras do "Programa Produtor de Água" (ANA): 2. Aplicação. R. Brasileira de Recursos Hídricos, Porto Alegre, v. 9, n. 3, p.15-21, 2004.

COMITÊ DA BACIA HIDROGRÁFICA DO RIO PARANAÍBA. Características físicas da bacia hidrográfica do ribeirão Pipiripau. Disponível em:

$<$ http://www.paranaiba.cbh.gov.br/BaciasTributarias/Legislacao/CaracteristicasFisicasBH Pipiripau.pdf $>$. Acesso em: 08 out. 2012.

COPE, V. Caracterização limnológica e balanço de massa de nutrientes, durante o enchimento das represas paraitinga e biritiba (alto tietê). 2008. 137 f. Dissertação (mestrado em Aqüicultura e Pesca) - Instituto de Pesca, Agência Paulista de Tecnologia dos Agronegócios, São Paulo, 2008.

CUNHA, J. F. et al. Balanço de nutrientes na agricultura brasileira. Informações Agronômicas, Piracicaba. 2010, n. 130, p. 1-11.

DIAS, L. E. e GRIFFITH J. J. Conceituação e caracterização de áreas degradadas. In: Dias, E. L.; Mello, J. W. V. Recuperação de áreas degradadas. Viçosa, [S.N], 1998, p.17.

EMPINOTTI, V. Pegada Hídrica: ferramentas de gestão, atores e seu impacto sobre as práticas de governança no Brasil. In: Congresso da Associação de Estudos Latino Americanos, San Francisco, Califórnia, 2012.

FREITAS, S.C. Estimativa da pegada hídrica cinza relativa ao fósforo na bacia hidrográfica do ribeirão pipiripau (DF/GO). 72 f. Dissertação (Mestrado em Ciências Florestais) - Departamento de Engenharia Florestal, Universidade de Brasília, Brasília, 2013.

GADOS, M.V. Perdas de fósforo e metais pesados por enxurrada em solo com aplicação de lodo de esgoto e cultivado com milho. 2003. 56 f. Dissertação (mestrado em agricultura tropical e subtropical) - Instituto Agronômico, Campinas, 2003. 
GEBLER, L. Comportamento do Arraste Superficial de Fósforo Reativo por Enxurrada sob Diferentes Coberturas Vegetais na Cultura da Maçã em Regime de Chuvas Simuladas. R. Brasileira de Recursos Hídricos, Porto Alegre, v. 17, n. 2, p. 101 110, 2012.

HANSEN, N. C. et al. The fate of phosphorus in agricultural systems. Soil and Water Conservation. [S.1]. 2002, v. 57, n. 6, p. $408-17$.

HGeo TECNOLOGIA EM GEOFÍSICA E GEOLOGIA. Universidade de Brasília. Relatório. Brasília, 2001.

HOEKSTRA A. Y E CHAPAGAIN A. K. Water footprints of nations: Water use by people as a function of their consumption pattern. Water Resour Manage, 2007. p. $35-48$.

HOEKSTRA, A. Y. et al. The Water Footprint Assessment Manual: setting the global standard. Washington: EARTHSCAN, 2011. 224 p.

HOEKSTRA, A.Y. Water neutral: reducing and off- setting the impacts of water footprints, Value of Water Research Report Series. n. 28, 2008.

HOEKSTRA, A.Y. e MEKONNEN, M.M. The water footprint of humanity. PNAS, Washington, v. 109, n. 9, p. 3232-3237, 2012.

HOEKSTRA, A.Y. e MEKONNEN, M.M. Global water scarcity: monthly blue water footprint compared to blue water availability for the world's major river basins, Value of Water Research Report Series No.53, UNESCO-IHE, 2011.

JENNY, H. Factors of soil formation. Nova York: McGraw Hill, 1941. 269 p.

LEENES, P.W. G e HOEKSTRA, A.Y. Business water footprint accounting: a tool to assess how production of goods and services impacts on freshwater resources worldwide. Value of water research report series, 2008.

LEOPOLD, A. Eutrophication of lakes. In: LEOPOLD, A. A Sand County Almanac: with essays on conservation from round river. ed.1. Estados Unidos: Ballantine Books, 1970, p. $185-219$.

LIMA, J.D. Bacia hidrográfica do Rio Piedade: mudanças ambientais. In: Simpósio Brasileiro de Geografia Física Aplicada, Viçosa, 2009.

LINDSAY, W. L. Chemical equilibria in soils. Nova York: Wiley, 1979, 449 p.

LITKE, D.W. Review of phosphorus control measures in the United States and their effects on water quality. Science in changing world. Colorado, 38 p., 1999.

LIU, C. et al. Past end future trends in grey water footprints of anthropogenic nitrogen and phosphorus inputs to major world rivers. Ecological Indicators. Netherlands. 2012. p. $42-29$. 
LOMBARDI NETO, F. e MOLDENHAUER, W.C. Erosividade da chuva: sua distribuição e relação com as perdas de solo em Campinas (SP). Bragantia, Campinas, v. 52, n. 2, p. 189-196, 1992.

LOPES, A. S. Solos sob "cerrado: Características, propriedades e manejo. ed. 2. Piracicaba: Associação Brasileira para Pesquisa da Potassa e do Fosfato, 1984. 162 p.

MAINSTONE, C.P. e PARR, W. Phosphorus in rivers: ecology and management. Science of The Total Environment. [S.I]. 2002, v. 282-283, p. 25-47.

McDOWELL, R. W., SHARPLEY, A. N., CONDRN, L.M. et al. Processes controlling soil phosphorus release to runoff and implications for agricultural management. Nutrient Cycling in Agroecosystems. [S.1]. 2001, v. 59, p. 269-284.

MUSETTI, R. A. Bacias hidrográficas no Brasil: aspecto jurídico-ambiental. CEJ, Brasília, n. 12, p. 90-94, 2000.

NOVAIS, R.F. et al. Fertilidade do solo. Viçosa, MG: UFV, 2007. 1017 p.

OLIVEIRA, J.R. Perdas de solo, água e nutrientes em um Argissolo VermelhoAmarelo sob diferentes padrões de chuva simulada. 2007. 52 f. Dissertação (Mestrado em Ciência do Solo) - Instituto de Agronomia, Universidade Federal Rural do Rio de Janeiro, Rio de Janeiro, 2007.

PAULINO W. D, FRANÇA, J. M. B. e FERREIRA, FERREIRA, A. C. S. Eutrofização dos corpos hídricos. 2007. Disponível em: <http://portal.cogerh.com.br>. Acesso em 26 nov. 2012.

PELLEGRINI, J. B. R. Fósforo na água e no sedimento na microbacia hidrográfica do Arroio Lino - Agudo - RS. 2005. 85 f. Dissertação (Mestrado em Ciências do Solo) - Centro de Ciências Rurais, Universidade Federal de Santa Maria, Santa Maria, 2005.

PINHEIRO, D.T.C. et al. Monitoramento da fertilidade do solo submetido à erosão hídrica em área cultivada com Eucalyptus sp. em São João Evangelista - MG. Agroambiental, São João Evangelista, p. 57-65, 2010.

PORTO, M.F. A e PORTO, R.L.L. Gestão de bacias hidrográficas. Estudos Avançados, São Paulo, v. 22, n. 63, p. 43-60, 2008.

QUINTON, J. N.; CATT, J. A. e HESS, T. M. The selective removal of phosphorus from soil: Is event size important? Journal of Environmental Quality, Madison. 2001, v. 30 , p. $538-545$.

RECKHOW, K.H.; BEAULAC, M.N.; SIMPSON, J.T. Modeling phosphorus loading and Lake Response under uncertainty: $A$ manual and compilation of export coefficients. Washington: U.S. Environmental Protection Agency. 1980, 224 p.

REICHERT, J. M. Formação de selo superficial e infiltração de água sob chuva 
simulada em solos do Rio Grande do Sul. 1988. 165f. Dissertação (Mestrado em Agronomia) - Universidade Federal do Rio Grande do Sul, Porto Alegre, 1988.

RENFRO, G. W. Use of erosion equations and sediment-delivery ratios for predicting sediment yields. In: RENFRO, G.W. Present and Prospective Technology for Predicting Sediment Yields and Sources, [S.1]: USDA-ARS-S-40. 1975, p. 33 - 45.

SALAS, H. J e MARTINO, P. A simplified phosphorus trophic state model for warmwater tropical lakes. Water Research. Lima. 1991, v. 25, n. 3., p. 341-350.

SANTANA, D.P. Manejo Integrado de Bacias Hidrográficas. Sete Lagoas: EMBRAPA, 2003. v. 30.

SAWYER, C. N., McCARTY, P. L. e PARKIN, G. F. Chemistry for Environmental Engineering and Science. ed. 5. Boston: McGraw-Hill, 2003, 768 p.

SCHICK, J. et al. Erosão hídrica em cambissolo húmico alumínico submetido a diferentes sistemas de preparo e cultivo do solo: perdas de nutrientes e carbono orgânico. R. Brasileira de Ciência do Solo. Viçosa, v. 24, n. 2, p. 437-447, 2000.

SECRETARIA DE INFRAESTRUTURA E OBRAS - SEINFRA-DF. Plano de gerenciamento integrado dos recursos hídricos do Distrito federal. PGIRH /DF. Relatório Temático Parcial 2. Brasília, 262 p., 2006.

SEIXAS, V.S.C. Análise da pegada hídrica de um conjunto de produtos agrícolas. 2011. 90 f. Dissertação (Mestrado em Engenharia do Ambiente, perfil de Gestão e Sistemas Ambientais) - Faculdade de Ciências e Tecnologia - Universidade de Lisboa, Lisboa, 2011.

SHARPLEY, A. N. CHAPRA, S. C. WEDEPOHL, R., et al. Managing agricultural phosphorus for protection of surfaces waters: Issues and options. Journal of Environmental Quality, Madison, 1994. v. 23, p. 437- 451.

SHARPLEY, A. N. Phosphorus cycling in unfertilized and fertilized agricultural soils. Soil Science Society of American Journal, Madison, 1985. v. 49, p. 905-911.

SHARPLEY, A. N. et al. The transport of bioavailable phosphorus in agricultural runoff. Journal of Environmental Quality, Madison, 1992. v. 21, p. 30-35.

SILVA, A. M. et al. Perdas de solo, água, nutrientes e carbono orgânico em cambissolo e latossolo sob chuva natural. Pesquisa agropecuária brasileira, Brasília, v. 40, n. 12, p. 1223-1230, 2005.

SORRENSON, W. J. e MONTOYA, L. J. Implicações econômicas da erosão do solo e de práticas conservacionistas no Paraná. Londrina: IAPAR/GTZ, 231p. 1984.

SOUZA, M.A. Análise da movimentação superficial e sub-superficial do glifosato na bacia hidrográfica do ribeirão Pipiripau - DF: um estudo de caso, 2013. Trabalho não publicado. 
STEEN-OLSEN, K et al. Carbon, Land, and Water Footprint Accounts for the European Union: Consumption, Production, and Displacements through International Trade. Environ. Sci. Technol. 2012, n. 46, p.10883-10891.

THE NATURE CONSERVANCY-TNC. Mapa de Uso do Solo da bacia do ribeirão Pipiripau. 2009. Formato digital.

TUNDISI, J. G. Recursos Hídricos: O futuro dos recursos. Multi Ciência. Brasil, v.1, p. 1$15,2003$.

VON SPERLING, M. Introdução à qualidade das águas e ao tratamento de esgotos. 3 . ed. Belo Horizonte, MG: UFMG, 2005. 425 p.

VON SPERLING, M. Estudos e modelagem da qualidade da água de rios. 1. ed. Belo Horizonte, MG: UFMG, 2007. 588 p.

UTTOMARK, P.D. et al. Estimating nutrient loading of lakes from non-point sources. $\mathrm{n}$. 660. Ecological Research Series, Oregon. 1974.

ZAFFANI, A.G. et al. A poluição da drenagem urbana relacionada com a pegada hídrica cinza: caso da cidade de São Carlos, SP. In: XIX Simpósio Brasileiro de Recursos Hídricos, Maceió, 2011.

XAVIER, C.F. Avaliação da influência do uso e ocupação do solo e de características geomorfológicas sobre a qualidade das águas de dois reservatórios da região metropolitana de Curitiba - Paraná. 2005. 167 f. Dissertação (mestrado em solos) - Universidade Federal do Paraná, Curitiba, 2005.

ZENG, Z. F. Assessing water footprint at river basin level: a case study for the Heihe River Basin in northwest China. Hydrol. Earth Syst. Sci. [S.1]. 2012, n. 16, p. 2771-2781. 